\title{
Review Article \\ Tumour Necrosis Factor Superfamily Members in the Pathogenesis of Inflammatory Bowel Disease
}

\author{
Tomasz J. Ślebioda and Zbigniew Kmieć \\ Department of Histology, Medical University of Gdańsk, Dębinki 1, 80-211 Gdańsk, Poland \\ Correspondence should be addressed to Tomasz J. Ślebioda; t.slebioda@gumed.edu.pl
}

Received 4 February 2014; Accepted 29 May 2014; Published 17 June 2014

Academic Editor: Arkadiusz Orzechowski

Copyright (C) 2014 T. J. Ślebioda and Z. Kmieć. This is an open access article distributed under the Creative Commons Attribution License, which permits unrestricted use, distribution, and reproduction in any medium, provided the original work is properly cited.

\begin{abstract}
Inflammatory bowel disease (IBD) is a group of inflammatory conditions of the gastrointestinal tract of unclear aetiology of which two major forms are Crohn's disease (CD) and ulcerative colitis (UC). CD and UC are immunologically distinct, although they both result from hyperactivation of proinflammatory pathways in intestines and disruption of intestinal epithelial barrier. Members of the tumour necrosis factor superfamily (TNFSF) are molecules of broad spectrum of activity, including direct disruption of intestinal epithelial barrier integrity and costimulation of proinflammatory functions of lymphocytes. Tumour necrosis factor (TNF) has a well-established pathological role in IBD which also serves as a target in IBD treatment. In this review we discuss the role of TNF and other TNFSF members, notably, TL1A, FasL, LIGHT, TRAIL, and TWEAK, in the pathogenesis of IBD.
\end{abstract}

\section{Introduction}

Inflammatory bowel disease (IBD) is a group of inflammatory conditions of the gastrointestinal (GI) tract. Its two major forms are ulcerative colitis (UC) and Crohn's disease (CD). Crohn's disease affects mainly small intestine and colon, although any other segment of the GI tract may also be involved. $\mathrm{CD}$ is characterized by discontinuous ulcerations and bowel wall inflammation. UC manifests by inflammation of the colon mucosa that in most cases extends to the rectum. Typical symptoms of IBD are abdominal pain, diarrhoea, and rectal bleeding as well as weight loss, fever, and fatigue. Furthermore, CD patients often develop strictures between segments of the bowel or between the bowel and other organs [1]. IBD is an autoimmune disorder of unknown aetiology that results from excessive immune responses to intestinal microbiota which are triggered by increased activity of effector $\mathrm{T}$ cells and/or decreased activity of regulatory $\mathrm{T}$ cells, changes in the composition of intestinal microflora, and/or damaged epithelial barrier [1, 2]. Recently, Hand et al. [3] showed in a mouse model that acute infection of the GI tract results in the loss of CD4(+) T cell tolerance of commensal antigens and priming of adaptive immune response directed against commensal bacteria which contributes to the development of IBD. Furthermore, 5-16\% of IBD patients report a family history of the disease [4] which indicates that it may be associated also with a genetic background. Indeed, there are several genetic factors that contribute to the pathogenesis of the IBD which include genetic mutations leading to enhanced inflammatory response [5-7], defective elimination of intracellular bacteria $[8,9]$, or disruption of the intestinal epithelial barrier [10]. There are also certain environmental risk factors for IBD that include (1) treatment with nonsteroidal anti-inflammatory drugs which damage intestinal mucosa, making it more permeable to bacteria; (2) taking oral contraceptives that elevate the level of estrogens which act as enhancers of humoral immunity; (3) smoking that increases risk of acquiring $\mathrm{CD}$, although it appears to play a protective role in UC through yet unknown mechanisms; and (4) limitation of exposure to enteric pathogens in childhood due to antibiotic treatment or living in hygienic environment [2]. Association of IBD with other environmental factors such as diet rich in sugars and fats and living in urban environment or stress remains currently controversial [2].

Considering the type of immune response, IBD is not a uniform disease; in $\mathrm{CD}$ the inflammation is mainly driven by $\mathrm{T}$ helper 1 (Th1) or T helper 17 (Th17) cells, while UC 
is considered to be generally a $\mathrm{T}$ helper 2- (Th2-) mediated condition [11]. It has to be noted, however, that the strict polarization model of Th1, Th2, and Th17 is not fully applicable in IBD due to a redundancy of effector and regulatory pathways affected by factors such as the phase of the disease (remission or acute bouts), innate inflammatory mechanisms, or anti-inflammatory treatment of patients [12]. For example, during the remission phase of the disease, the level of a Th2 cytokine, interleukin 13 (IL-13), is higher in peripheral blood mononuclear cells (PBMCs) isolated from patients with $\mathrm{CD}$ than in PBMCs isolated from patients with UC [13]. Other reports show that the frequency of Th1 (IFN- $\gamma(+)$ CD4(+)) T cells is lower in the peripheral blood of paediatric IBD patients than in healthy control subjects $[14,15]$ and it increases with patients' age [15]. Furthermore, the cytokine expression profile in IBD patients does not usually reflect fully differentiated Th1, Th2, or Th17 immune responses [12]. In UC, expression of a typical Th2 cytokine, IL-4, was not elevated in intestinal mucosa of UC patients [12]. Instead, it has been suggested that the central role in the pathogenesis of UC is played by IL-13 $[12,16]$ which not only acts as a Th2 effector cytokine [17] but also disrupts the continuity of colonic epithelium by inducing apoptosis of epithelial cells and upregulating expression of claudin2 , a pore-forming tight junction protein [18]. To add more complexity to the pathogenesis of IBD, a recent report by Mannon et al. [19] has showed that in some patients UC is characterized by elevated production of a Th17-specific cytokine, IL-17A, by intestinal lamina propria $\mathrm{T}$ cells.

\section{Tumour Necrosis Factor Superfamily}

There are 19 ligands and 29 receptors identified to date that constitute the tumour necrosis factor superfamily (TNFSF) [20]. Their expression pattern and structural attributes allow them to activate signalling pathways that lead to cell survival, proliferation, differentiation, or apoptosis. TNFSF receptors can be divided into two groups depending on the presence or absence of the intracellular death domain (DD). Signalling via the death domain requires the participation of adaptor proteins FADD (Fas-associated death domain) and TRADD (TNF receptor-associated death domain) and leads to activation of caspases which typically results in apoptotic death of a cell [21]. The second group of TNFSF receptors signals only via adaptor proteins termed TRAFs (tumour necrosis factor receptor-associated proteins), although DDcontaining receptors can also utilize this pathway. TRAFs bind either to TRADD or directly to the cytoplasmic part of the receptor and initiate signal transduction pathways that lead to the activation of several transcription factors, such as AP-1 and NF- $\kappa$ B, responsible for the activation of prosurvival genes [21], although they are involved also in proapoptotic signalling [22-24]. Hence, functional activity of TNFSF receptors largely depends on the cellular context and the balance between pro- and antiapoptotic factors inside the cell and in the environment.

Most TNFSF members are expressed on cells of the immune system and play an important role in maintaining the equilibrium of $\mathrm{T}$ cell-mediated immune responses by providing direct signals required for full activation of effector and regulatory $\mathrm{T}$ cells, regulation of their expansion, contraction of the $\mathrm{T}$ cell effector pool, and survival of memory $\mathrm{T}$ cells [2530]. For these reasons, members of the TNFSF are involved in the pathogenesis of many $\mathrm{T}$ cell-mediated autoimmune diseases, such as asthma, diabetes, or arthritis [26]. Many recent reports indicate that certain TNFSF members, notably, TNF (tumour necrosis factor, TNFSF2, also known as TNF$\alpha)$ [31], TL1A (TNF-like protein 1A, TNFSF15) [32, 33], FasL (TNFSF6) [34-36], LIGHT (lymphotoxin-like inducible protein that competes with glycoprotein $\mathrm{D}$ for binding herpesvirus entry mediator on T cell, TNFSF14) [37], TRAIL (TNF-related apoptosis inducing ligand, TNFSF10) [38], and TWEAK (TNF-like weak inducer of apoptosis, TNFSF12) [39], contribute to the pathogenesis of IBD not only by enhancing proinflammatory function of $\mathrm{T}$ cells but also by direct disruption of the integrity of intestinal epithelium (Table 1).

\section{TNF}

Tumour necrosis factor (TNF; TNF- $\alpha$; TNFSF2) is biologically active in the form of homotrimeric transmembrane or soluble protein [40]. It is expressed by macrophages, $\mathrm{T}$ cells, B cells, NK cells, mast cells, endothelial cells, fibroblasts, and neurons; its expression is strongly upregulated by certain proinflammatory factors such as lipopolysaccharide (LPS) or other bacterial products and IL- $1 \beta[20,24,41]$. There are two types of TNF receptors, the death domain-containing TNFR1 (TNF receptor 1, also known as p55 or TNFRSF1A), which is constitutively expressed on most nucleated mammalian cells and is activated by both the transmembrane and soluble form of TNF [20], and TNFR2 (TNF receptor 2, also known as p75 or TNFRSF1B) which does not contain the death domain and is activated only by the transmembrane form of TNF [24]. Expression of TNFR2 is strictly regulated and found mostly on certain populations of lymphocytes, including Tregulatory cells (Tregs), endothelial cells, microglia, neuron subtypes, oligodendrocytes, cardiac myocytes, thymocytes, and human mesenchymal stem cells [20,42].

Elevated expression of TNF was detected in IBD patients more than 20 years ago [52]. The level of TNF mRNA was upregulated in involved colonic tissue of $\mathrm{CD}$ patients [53] as well as in both involved and uninvolved colonic tissue of UC patients [54] compared to healthy subjects. A recent report [55] showed that elevated concentration of TNF protein that correlated with the activity of the disease was present in blood serum of $\mathrm{CD}$ patients while other groups $[52,56]$ found increased levels of TNF protein both in serum $[52,56]$ and in the intestinal lamina propria of both $\mathrm{CD}$ and UC patients as well as the intestinal submucosa of CD patients [57]. The production of TNF in the colon mucosa of UC patients was localized to lamina propria macrophages [57]. Although several groups did not detect increased levels of TNF protein or mRNA in blood serum or colon mucosa of IBD patients, respectively $[58,59]$, successful use of anti-TNF agents in IBD therapy [31] documents that TNF belongs to 
TABLE 1: Overview of the expression and function of the major members of TNSF superfamily in IBD.

\begin{tabular}{|c|c|c|c|}
\hline $\begin{array}{l}\text { TNFSF member and } \\
\text { its expression }\end{array}$ & Receptors and their expression & Role in IBD pathogenesis & References \\
\hline $\begin{array}{l}\text { TNF-macrophages, } \\
\text { NK cells, T cells, and } \\
\text { B cells }\end{array}$ & $\begin{array}{l}\text { (i) TNFR1-intestinal epithelial cells } \\
\text { (ii) TNFR2-intestinal epithelial cells }\end{array}$ & $\begin{array}{l}\text { Disruption of intestinal epithelium } \\
\text { integrity by induction of adhesion } \\
\text { proteins rearrangement and induction of } \\
\text { intestinal cells apoptosis }\end{array}$ & {$[20,43,44]$} \\
\hline $\begin{array}{l}\text { TL1A-antigen- } \\
\text { presenting cells and T } \\
\text { cells }\end{array}$ & $\begin{array}{l}\text { (i) DR3 - T cells, NK cells, NKT cells, and } \\
\text { regulatory T cells } \\
\text { (ii) DcR3 (decoy) - activated T cells }\end{array}$ & $\begin{array}{l}\text { Promotion of proinflammatory activity of } \\
\mathrm{T} \text { cells and inhibition of suppressive } \\
\text { activity of regulatory T cells }\end{array}$ & {$[45,46]$} \\
\hline $\begin{array}{l}\text { FasL-T cells, NK } \\
\text { cells, monocytes, and } \\
\text { Paneth cells }\end{array}$ & $\begin{array}{l}\text { (i) Fas_intestinal epithelial cells and T cells } \\
\text { (ii) DcR3 (decoy)_-activated T cells }\end{array}$ & $\begin{array}{l}\text { Possible disruption of intestinal } \\
\text { epithelium integrity by induction of } \\
\text { epithelial cells apoptosis. Possible } \\
\text { involvement in accumulation of } \\
\text { proinflammatory T cells in intestinal } \\
\text { lamina propria }\end{array}$ & {$[20,47,48]$} \\
\hline $\begin{array}{l}\text { LIGHT-T cells, } \\
\text { monocytes, } \\
\text { granulocytes, and } \\
\text { dendritic cells }\end{array}$ & $\begin{array}{l}\text { (i) HVEM-T cells, B cells, and monocytes } \\
\text { (ii) LT } \beta \text { R-nonlymphoid hematopoietic } \\
\text { cells and stromal cells } \\
\text { (iii) DcR3 (decoy)—activated T cells }\end{array}$ & $\begin{array}{l}\text { Possible promotion of proinflammatory } \\
\text { activity of Thl cells }\end{array}$ & {$[20,49]$} \\
\hline $\begin{array}{l}\text { TRAIL_intestinal } \\
\text { epithelium, T cells, } \\
\text { NK cells, and } \\
\text { dendritic cells }\end{array}$ & $\begin{array}{l}\text { (i) TRAIL-R1-almost all cell types } \\
\text { (ii) TRAIL-R2-almost all cell types } \\
\text { (iii) TRAIL-R3 (decoy) - almost all cell types } \\
\text { (iv) TRAIL-R4 (decoy)-almost all cell types } \\
\text { (v) OPG (decoy) - osteoclasts' precursors, } \\
\text { endothelial cells, and other cell types }\end{array}$ & $\begin{array}{l}\text { Disruption of intestinal epithelium } \\
\text { integrity by induction of epithelial cells } \\
\text { apoptosis. Possible contribution to } \\
\text { development of fistulas and strictures in } \\
\text { CD patients }\end{array}$ & {$[20,38,50]$} \\
\hline $\begin{array}{l}\text { TWEAK-T cells, } \\
\text { macrophages, and } \\
\text { dendritic cells }\end{array}$ & Fn14-intestinal mucosa and fibroblasts & $\begin{array}{l}\text { Possible upregulation of proinflammatory } \\
\text { cytokines and infiltration of lamina } \\
\text { propria by inflammatory cells. Induction } \\
\text { of intestinal cells apoptosis in } \\
\text { cooperation with IL-13 }\end{array}$ & {$[20,39,51]$} \\
\hline
\end{tabular}

the major effector molecules involved in the pathogenesis of CD and UC. It is worth to note, however, that a recent study on a mouse model of $\mathrm{T}$ cell-mediated colitis has shown that only neutralization of the transmembrane, but not soluble, TNF form induced remission of experimental colitis [60]. Pathogenesis of IBD is associated also with altered expression of TNF receptors since both CD and UC patients showed elevated expression of TNFR2 on colonic epithelial cells [61]. Moreover, a positive correlation was observed between $\mathrm{CD}$ and UC activity and serum concentration of soluble forms of TNFR1 and TNFR2 [55]. Furthermore, upregulated expression of TNFR2 (but not TNFR1) was found on intestinal lamina propria $\mathrm{CD} 4^{+}$cells as well as peripheral blood $\mathrm{T}$ cells of CD patients [62].

\subsection{Role of TNF in the Dysregulation of Intestinal Barrier} Permeability. Several studies showed that TNF contributes to the disruption of intestinal epithelial barrier which allows for intestinal penetration of luminal antigens and promotes intestinal inflammation (Table 2) [63-65]. Intestinal epithelium integrity is provided by the presence of tight junctions (TJ) located in the apical region of intestinal epithelial cells. Data obtained in vitro by $\mathrm{Ma}$ et al. [63] showed that stimulation of colonic epithelial Caco-2 cells with TNF downregulated the expression of TJ-associated zonula occludens-1 proteins and altered their junctional localization in an NF$\kappa \mathrm{B}$-dependent manner.

Transmembrane expression of TNF is regulated by a pleiotropic metalloproteinase ADAM17 which is involved in the cleavage of transmembrane TNF and its shedding from the cell surface [66]. Cesaro et al. [67] reported early posttranscriptional upregulation of ADAM17 in intestinal mucosa of patients with highly active CD and, in an in vitro model, in intestinal epithelial cells, which was linked to transepithelial migration of polymorphonuclear neutrophils. Treatment of TIMP3-deficient colonic epithelial cell line HT29-C1.16E with TIMP3, an inhibitor of ADAM17 activity, decreased TNF shedding and sensitized the cells to TNF-mediated epithelial hyperpermeability due to the downregulation of zonula occludens-1 proteins [64]. Other reports showed that IBD patients had also elevated mucosal expression of another TNF sheddase, metalloprotease ADAM19, localized mainly in epithelial cells [68], whereas a mouse study demonstrated that shedding of TNF can be mediated also by matrix metalloproteinase 13 (MMP13) [69].

Epithelial barrier dysfunction can be mediated also by increased expression of myosin light chain kinase (MLCK) followed by subsequent phosphorylation of myosin II regulatory light chain (MLC) which results in the contraction of the perijunctional ring composed of actin and myosin 
TABLE 2: Biological effects of TNF exerted on intestinal epithelium.

\begin{tabular}{|c|c|c|}
\hline TNF function & Model & References \\
\hline \multicolumn{3}{|c|}{ (1) Rearrangement of cytoskeletal elements } \\
\hline $\begin{array}{l}\text { (i) Downregulation of zonula occludens-1 expression and } \\
\text { alteration of its intracellular localization }\end{array}$ & $\begin{array}{l}\text { (i) Caco-2 cells (in vitro) } \\
\text { (ii) HT29-C1.16E cells (in vitro) }\end{array}$ & {$[63,64]$} \\
\hline (ii) Upregulation of myosin light chain kinase expression & $\begin{array}{l}\text { (i) Caco-2 cells (in vitro) } \\
\text { (ii) Mouse model (in vivo) }\end{array}$ & {$[65,70]$} \\
\hline $\begin{array}{l}\text { (iii) Redistribution of zonula occludens-1, occludins, claudins, } \\
\text { E-cadherins, and myosin light chain kinase to basolateral } \\
\text { membranes of intestinal cells }\end{array}$ & Mouse model (in vivo) & {$[71]$} \\
\hline \multicolumn{3}{|c|}{ (2) Induction of intestinal epithelial cells' apoptosis } \\
\hline (i) Induction of intestinal cells' apoptosis via activation of caspase-3 & Mouse model (in vivo) & [71] \\
\hline $\begin{array}{l}\text { (ii) Induction of intestinal epithelial cells' apoptosis via } \\
\text { upregulation of iNOS and p53 }\end{array}$ & Mouse model (in vivo) & {$[44,72]$} \\
\hline
\end{tabular}

filaments [73]. Expression of MLCK was elevated in ileal and colonic epithelium of CD and UC patients and correlated with the activity of the disease [74]. In vitro investigation showed that TNF upregulated expression of MLCK in Caco- 2 cells pretreated with IFN- $\gamma$ which increased expression of TNF receptors on the cell surface [65]. A recent study on TNFR1 or TNFR2-deficient mice showed that upregulation of MLCK and the loss of intestinal epithelial barrier in CD4(+) CD45RB (high) T cell transfer model of intestinal inflammation were dependent on TNFR2 expressed on intestinal epithelium but not TNFR1 [70].

In an elegant in vivo study on mouse models, Marchiando et al. [71] showed that TNF induced redistribution of several TJ and adherens junction proteins, including zonula occludens-1, occludins, claudins, and E-cadherin, as well as MCLK, to basolateral membranes of intestinal epithelial cells. Furthermore, administration of TNF resulted not only in the rearrangement of junctional proteins but also in the shedding of whole cells from intestinal epithelium. These events were preceded by caspase- 3 activation due to the TNFinduced activation of NF- $\kappa \mathrm{B}$-dependent signalling pathway and of proapoptotic pathways [71]. These data suggest that TNF-triggered loss of intestinal epithelium integrity is a complex process which involves not only rearrangement of cytoskeletal elements but also direct induction of intestinal cells' apoptosis by TNF. Indeed, studies on mice showed TNFinduced apoptosis of intestinal epithelial cells in a TNFR1and TNFR2-dependent manner [44, 72] which resulted in increased intestinal permeability in vivo [44]. TNF signalling upregulated expression of inducible nitric oxide synthase (iNOS) which led to enhanced expression of a proapoptotic protein p53 [72]. On the other hand, TNF participates also in transactivation of epidermal growth factor receptor (EGFR) [75] which signaling upregulates the expression of cyclooxygenase-2 (COX-2) [76]. Increased expression of COX-2 has been associated with enhanced cell resistance to apoptosis, inflammation, and promotion of tumour progression [77]; therefore this aspect of TNF activity might have relevance to development of IBD-associated cancers of the GI tract [78].
3.2. Anti-TNF Agents in IBD Therapy. Currently, IBD therapy based on blocking biological activity of TNF involves the use of the following anti-TNF agents approved by Food and Drug Administration (FDA) and European Medicines Agency (EMA): (1) infliximab: chimeric monoclonal antiTNF antibody (approved by FDA and EMA for treatment of CD and UC); (2) adalimumab: human monoclonal antiTNF antibody (approved by FDA for treatment of CD in adults and by EMA for treatment of CD and UC); (3) certolizumab pegol: humanized Fab' fragment of anti-TNF antibody conjugated to polyethylene glycol (approved by FDA only for treatment of CD) [79]; (4) golimumab: human monoclonal anti-TNF antibody (approved by FDA and EMA for treatment of UC) [80]. Infliximab, adalimumab [81], and certolizumab pegol [82] are effective in the treatment of patients with moderate and severe CD who do not respond to standard anti-inflammatory drugs and also when used as a first-line therapy in CD. Moreover, randomised, controlled trials showed also that infliximab $[83,84]$, adalimumab [85, $86]$, and golimumab $[87,88]$ induced remission in steroidor immunosuppressant-refractory patients with moderate or severe UC. However, 10 to $40 \%$ of CD patients (depending on selection criteria) and up to $50 \%$ of UC patients do not respond to anti-TNF therapy (primary resistance) and about one-third become resistant (secondary loss of response) at 12 months after initiation of anti-TNF treatment [89-91]. Interestingly, switching to another anti-TNF agent is effective in over $50 \%$ of nonresponsive patients $[92,93]$. Failure to respond to anti-TNF therapy may result from pharmacokinetics of drugs, development of antibodies against the drugs, or activity of other, TNF-independent, proinflammatory pathways in IBD patients [91, 94, 95].

It has also to be noted that blockade of TNF biological activity in IBD therapy may result in several adverse side effects [82], including acute or delayed hypersensitivity reactions to anti-TNF agents $[96,97]$, elevated risk of bacterial, mycobacterial, viral, and fungal infections [98] (although meta-analysis of clinical trials did not show increased rate of infections in the course of anti-TNF treatment [89]), or neurological complications [99-101]. Combinatory therapy of $\mathrm{CD}$ patients with glucocorticoids, immunomodulators, 
and TNF inhibitors may be associated with an increased risk of non-Hodgkin's lymphoma, lung, skin, and other types of cancers, although no causative relationship of anti-TNF antibodies and carcinogenesis has been proven [90]. AntiTNF therapy may lead also to paradoxical inflammatory skin (eczema and psoriasis) and joint (polyarthralgia) or ocular (uveitis and scleritis) manifestations [102]. Other paradoxical reactions include also demyelinating central nervous system disorders, sarcoidosis, development of anti-nuclear antibodies, and, in rare cases, lupus [89]. Mechanisms leading to these paradoxical reactions are not currently well known and most probably involve multiple pathogenic pathways. For example, it has been recently reported that psoriasiform skin lesions characterised by Th17 and Th1 cell infiltrates developed in nearly $5 \%$ of anti-TNF-treated patients with IBD and that smoking was identified as a main risk factor. Interestingly, anti-IL-12/IL-23 antibody treatment was found to be a highly effective therapy for these lesions [103].

Despite high efficacy of the majority of anti-TNF antibodies in the therapy of a considerable proportion of both CD and UC patients [90], the precise mechanisms of action underlying the efficacy of anti-TNF agents in IBD therapy have not been fully explained. In the last decade multiple mechanisms of the anti-TNF antibodies such as blocking and neutralizing of TNF molecules, regulation of cell adhesion molecule expression, induction of regulatory macrophages, or direct induction of apoptosis of $\mathrm{T}$ lymphocytes and macrophages in the mucosal lamina propria and peripheral blood have been proposed [104, 105]. However, the results of newer studies suggest that increased apoptosis of Treg cells, an important subset of T lymphocytes, may play an important role in the pathogenesis of IBD and can be reversed by antiTNF $\alpha$ treatment $[106,107]$. Moreover, infliximab and adalimumab (but not etanercept and certolizumab) were shown to induce regulatory macrophages (CD206+) in an Fc regiondependent manner. In vitro these macrophages produced anti-inflammatory cytokines and inhibited proliferation of activated T cells [108], whereas in vivo a significant induction of regulatory macrophages was observed in IBD patients with mucosal healing after treatment with infliximab and this induction was absent in patients without mucosal healing response [109].

Recently, Leal et al. [110] using whole-genome transcriptional analysis have found that anti-TNF treatment reduced expression of a set of proinflammatory genes (including IL6, IL-23p19, and MMP9) as well as genes of cell-activation markers (CD69, CD83, and VCAM-1) in patients who both did and did not respond to this kind of therapy, suggesting that it is not only the proinflammatory function of TNF that is targeted by anti-TNF therapy. Moreover, they identified IL1B and IL17A as genes that remained altered in nonresponders, which suggests that respective proteins or their signaling pathways may present a novel therapeutic target in IBD.

Since many studies have linked TNF to increased permeability of intestinal epithelium [63-65], it is highly possible that anti-TNF agents are involved in the protection of epithelial barrier. Indeed, administration of infliximab restored the proper function of intestinal epithelium in CD patients $[42,111]$ and prevented TNF-induced rearrangement of tight junction proteins (notably, occludin and zonula occludens1) in dinitrobenzene sulfonic acid- (DNBS-) induced colitis in mice [112]. These findings have been supported by a recent in vitro study on intestinal epithelial cell lines Caco-2 and T84 which showed that adalimumab restored expression of tight junction proteins claudin-1, claudin-2, and claudin-3 downregulated by exposure to TNF and IFN$\gamma$ [113]. Other studies demonstrated that infliximab and adalimumab induced apoptosis of CD4(+) helper $\mathrm{T}$ cells expressing TNFR2 and macrophages isolated from colonic lamina propria of CD patients but not healthy subjects [23]. Furthermore, Eder et al. [114, 115] found that infliximab and adalimumab promoted apoptosis of intestinal lamina propria mononuclear cells present in inflamed but not noninflamed areas of CD patients' colonic mucosa via intrinsic pathway mediated by Bcl-2 family proteins. Thus, infliximab and adalimumab not only protect intestinal epithelial integrity but also may suppress inflammatory process by inducing apoptosis of immune cells present in intestinal mucosa.

The ongoing research aimed at the elucidation of the cellular and molecular mechanisms of the anti-inflammatory activity of some but not all anti-TNF antibodies in IBD should help in designing more target-effective biological drugs. Etanercept, a nonantibody soluble fusion protein composed of the extracellular domain of TNFR2 and the hinge and Fc fragments of human IgG1 antibody [116], is an antiTNF agent approved by FDA and EMA for treatment of rheumatoid arthritis, psoriasis, psoriatic arthritis, ankylosing spondylitis, and juvenile idiopathic arthritis but not IBD. Even though experiments on mice with DNB-induced colitis showed that etanercept reduced levels of circulating TNF and prevented apoptosis of enterocytes equally well as infliximab [112], studies on humans proved that response rates to etanercept in $\mathrm{CD}$ treatment were comparable to placebo [117]. A study by Scallon et al. [116] showed that infliximab binds both monomeric and trimeric forms of soluble and transmembrane TNF, whereas etanercept forms only unstable complexes with soluble TNF which may contribute to prolonged half-life of circulating TNF. Furthermore, in contrast to infliximab, etanercept did not induce apoptosis of activated $\mathrm{T}$ cells isolated from $\mathrm{CD}$ patients and healthy control subjects [104]. The failure of etanercept in IBD therapy can be attributed to its inability, in contrast to infliximab and adalimumab, to inhibit $\mathrm{T}$ cell proliferation and to induce regulatory macrophages [108], caused probably by differences in infliximab and etanercept binding to TNF.

\section{TL1A}

TL1A (TNF-like molecule 1A; TNFSF15) is the most recently discovered member of the TNF superfamily, identified for the first time in 2002 [118]. In humans, there are three different isoforms of the protein generated from TNFSF15gene as a result of alternative splicing: VEGI-174 (174 amino acids), VEGI-192 (192 amino acids), and the full-length product, TL1A (VEGI-252; 252 amino acids) [118-120], although VEGI-174 is most probably a cloning artefact [118]. Primary function of VEGI-192 is the inhibition of 
angiogenesis [121], whereas TL1A is a proinflammatory factor involved in the pathogenesis of several autoimmune diseases, including arthritis, allergic lung inflammation, autoimmune encephalomyelitis, and inflammatory bowel disease $[26,122-$ 124].

Similarly to TNF, TL1A exists in a soluble or transmembrane form [125-128]. It has been shown that recombinant human TL1A forms a homotrimer resembling the trimeric structure of other TNF superfamily members [129]; however, still very little is known about the quaternary structure of the native form of TL1A molecule.

TL1A expression is primarily found on activated cells of the immune system, such as dendritic cells, macrophages [128], and CD4(+) and CD8(+) T cells [122, 123], whereas very little TL1A was found on nonactivated immune cells [118]. Known inducers of TL1A expression are TNF, IL-1 [118], Fc fragments of IgG1 antibodies [128], and certain parasite- or bacteria-related toll-like receptors (TLR) ligands, including synthetic bacterial lipoprotein Pam3CSK4 (ligand for TLR1 and TLR2), lipopeptide FSL (ligand for TLR2), polyinosinicpolycytidylic acid (ligand for TLR3), LPS (ligand for TLR4), single-stranded RNA (ligand for TLR7), unmethylated DNA sequences (ligands for TLR9), and tachyzoite antigen (ligand for TLR11) $[123,130]$.

The main receptor for TL1A is death receptor 3 (DR3; TNFRSF25) [118], structurally similar to TNFR1 [131]. DR3 was found to be strongly upregulated on activated monocytes [132], NK cells [133], NKT cells [122], and B cells [134], as well as CD4(+) T helper and CD8(+) T cytotoxic cells $[133,135]$. TL1A, similarly to FasL and LIGHT, binds also soluble decoy receptor 3 (DcR3, TNFRSF6B) which prevents functional TL1A/DR3 signalling $[127,136]$.

Even though DR3 contains the death domain, TL1A has been shown to induce apoptosis only in the erythroleukaemic cell line TF-1 treated with an inhibitor of protein synthesis, cycloheximide (CHX) [118, 137]. In activated T cells, however, TL1A did not induce apoptosis even in the presence of $\mathrm{CHX}$ [118]. Instead, TL1A/DR3 interactions in lymphocytes triggered proliferative and costimulatory signals through activation of NF- $\kappa \mathrm{B}$-mediated pathways $[123,133]$. Thus, TL1A is a proinflammatory molecule which primarily costimulates proliferation and effector functions of CD8(+) cytotoxic T cells [138] as well as Th1, Th2, and Th17 [30, 123, 126, 139, 140] cells in the presence of TCR stimulation; however, in physiological conditions, TL1A is not required for the differentiation of these lymphocytes [123]. Furthermore, TL1A promotes also maturation of dendritic cells [141, 142] and production of proinflammatory cytokines (TNF, IL-8, and monocyte chemotactic protein 1, MCP-1) by macrophages [132]. Apart from conventional CD4(+) and CD8(+) T cells, TL1A/DR3 interaction promotes also proliferation of regulatory $\mathrm{T}$ cells (Tregs) [143, 144], although sustained TL1A stimulation in vitro dampens suppressive activity of Tregs [143-145]. Interestingly, in vitro studies also showed that TL1A inhibited differentiation of Tregs from their precursor cells $[143,145]$.

Certain alleles of TNFSF15gene which encode TL1A are associated with enhanced activity of TNFSF15promoter region and are considered to increase susceptibility to Crohn's disease [146]. TL1A protein and mRNA were upregulated in
IBD and their synthesis was localized in CD patients to lamina propria infiltrating cells such as macrophages, dendritic cells, and CD4(+) and CD8(+) T cells $[139,140,147]$ as well as plasma cells isolated from colon mucosa of UC patients [125]. IBD patients had also a higher proportion of DR3expressing lamina propria $\mathrm{T}$ cells than healthy subjects $[125$, 126] and the amount of TL1A protein as well as the number of TL1A-positive cells correlated positively with the severity of inflammation, most significantly in CD [125]. Furthermore, studies on transgenic mice showed that constitutive elevated expression of TL1A on T cells or dendritic cells resulted in enhanced $\mathrm{T}$ cell activation and upregulation of IL-13, IL-17A, and IFN- $\gamma$ mRNA levels in intestinal mucosa and mesenteric lymph nodes as well as spontaneous development of bowel inflammation $[143,144]$.

Recently, a population of CD161(+)CD4(+) T cells has been identified as a primary target of TL1A in IBD [148], although other subpopulations of $\mathrm{T}$ cells may also respond to TL1A costimulation. CD161(+)CD4(+) T cells express DR3 [149] and their gut tropism is established by high expression of intestine-homing molecules such as integrin $\beta 7$ and chemokine CCR6 $[149,150]$. They bear characteristics of Th17 cells and have been shown to produce proinflammatory cytokines IL-17, IL-22, and IL-13. In inflammatory conditions, however, they may revert their phenotype to Th1 type and produce IFN- $\gamma$ [149-151]. In synergy with other proinflammatory cytokines, such as IL-12 and IL-18 or IL-23, TL1A further enhances the inflammatory process by increasing production of IFN- $\gamma$, IL-8, and IL- 6 by lymphocytes $[30,125$, $139,140]$. Thus, TL1A involvement in IBD pathomechanisms may result from enhanced costimulation of effector $\mathrm{T}$ cells and local upregulation of proinflammatory cytokines production in parallel to defective generation of peripheral Tregs and inhibition of suppressive activity of preexisting Tregs $[45,46]$.

As one of the key regulators of inflammatory pathways, TL1A appears to be a promising therapeutic target for patients with $\mathrm{T}$ cell-mediated autoimmune diseases, including IBD, although to this day none of TL1A blocking agents has yet been tested in clinical trials. There are, however, reports showing that antibody-mediated inhibition of TL1A biological activity prevents the development of dextran sodium sulphate- (DSS-) induced and T cell transfer-induced experimental bowel inflammation in mice [139].

\section{FasL}

Fas ligand (FasL, CD95L, and TNFSF6) and its receptor Fas (CD95, TNFRSF6) are other members of the TNF superfamily involved in the pathogenesis of IBD. Cytotoxic T cells and natural killer (NK) cells use FasL to kill tumour cells or viruses-infected cells which express Fas. FasL is involved also in maintaining immune homeostasis and preventing autoimmunity via a mechanism known as activation-induced cell death (AICD) which relies on killing activated $\mathrm{T}$ cells following their expansion and differentiation in a FasL-/Fasdependent manner, thus preventing hyperactivation of T cellmediated immunity $[47,152]$. 
FasL is a transmembrane molecule, although it can be enzymatically cleaved from cells [153]. An in vivo mouse study showed, however, that only the transmembrane, but not soluble, FasL was capable of triggering cell death [154]. In contrast to Fas which is constitutively or inducibly expressed on many different cell types, including colon epithelial cells [155], FasL expression is tightly regulated and limited to activated CD4(+) and CD8(+) T cells, NK cells, and monocytes [47]. In physiological conditions, Paneth cells are the only cells of the intestinal epithelium which express FasL [156]. Expression of FasL was found also in tissues and organs that lack resident or infiltrating lymphocytes (e.g., eye, trophoblast, or testis) and on neurons and astrocytes as well as in several tumours where it may contribute to the suppression of local immune responses via induction of $\mathrm{T}$ cell apoptosis [47].

The majority of studies concerning the role of FasL and Fas in IBD have been conducted in patients with ulcerative colitis rather than Crohn's disease. Expression of FasL was significantly elevated on CD3(+) lymphocytes infiltrating colonic lamina propria in patients with active UC but not in $\mathrm{UC}$ remission, active or remission $\mathrm{CD}$, or healthy subjects [34, 35]. Furthermore, serum concentration of systemic soluble Fas was lower in patients with active UC compared to healthy controls [35]. Nevertheless, there are also studies which showed upregulation of FasL in colonic lamina propria and intraepithelial lymphocytes of CD patients' mucosa [36].

The exact role of Fas/FasL system in IBD has not been fully elucidated. Taking into account the primary, proapoptotic function of Fas/FasL signalling, its possible role in IBD initially appeared to be similar to TNF/TNFR1 signalling: intestinal epithelial cells expressing Fas targeted by FasL(+) lymphocytes undergo apoptosis which may lead to the increased permeability of intestinal epithelium [157]. Indeed, an in vitro study demonstrated that ligation of Fas resulted in apoptotic death of intestinal epithelial cells isolated from mucosa of UC patients [158]. This concept was supported also by the fact that in healthy colon expression of FasL was restricted only to few mononuclear cells of lamina propria, suggesting that proapoptotic function of Fas/FasL system was not involved in regeneration of colonic epithelium but in pathogenesis of IBD [159]. A more recent study, however, showed that colonocytes isolated from patients with active UC had attenuated response to Fas-mediated apoptosis induction compared to healthy subjects and patients in remission [160]. Furthermore, authors of two mouse studies demonstrated that Fas-deficient mice were hypersensitive to dextran sodium sulphate- (DSS-) induced colitis [161] and did not show any significant reduction in tissue damage, even though they exhibited an increased rate of intestinal epithelial cell apoptosis in gut inflammation model based on administration of $\mathrm{T}$ cell activating anti-CD3 antibody [162]. These findings suggest that colonocytes may activate cytoprotective programs in response to inflammation and may not be oversensitive to Fas-dependent apoptosis as had been initially proposed [160].

Several studies showed that $\mathrm{T}$ cells from inflamed mucosa of CD and UC patients were more resistant to Fas-mediated apoptosis than control $\mathrm{T}$ cells from healthy individuals [163-165]. Suzuki et al. [166] found that in UC mucosa the population of $\mathrm{CD} 45 \mathrm{RO}(+) \mathrm{CD} 4(+) \mathrm{T}$ cells was less prone to Fas-mediated cell death than the population of $\mathrm{CD} 45 \mathrm{RO}(+) \mathrm{CD} 8(+) \mathrm{T}$ cells. Thus, potentially harmful, proinflammatory $\mathrm{T}$ cells may accumulate in the intestinal mucosa of IBD patients and induce tissue damage.

Fas and FasL, while playing an important role in the regulation of apoptosis, have also nonapoptotic functions. Fas contains the death domain and, in contrast to TNFR1, had been thought to be involved only in proapoptotic but not prosurvival signalling [167]. However, it has been shown recently that although strong Fas stimulation blocked activation of human CD4(+) helper T cells, weak Fas stimulation together with TCR signalling augmented their proliferation via activation of MAP kinases, transcription factors, and cell cycle activators [168].

FasL contributes to costimulation of $\mathrm{T}$ cells also by a phenomenon termed "reverse signalling." Under this condition ligation of transmembrane FasL by functional Fas or DcR3 (a soluble decoy receptor for FasL, TL1A, and LIGHT) triggers signal transduction from FasL, resulting in the enhanced proliferation of mouse CD8(+) cytotoxic T cells [169-172]. These findings add much more complexity to possible roles of Fas/FasL system in the pathomechanisms of IBD which, theoretically, can be involved not only in direct disruption of epithelial continuity but also in costimulation of proinflammatory T cells. Since the details of Fas/FasL role in IBD still remain largely unknown, agents directly interfering with Fas signalling have yet not been tested for IBD treatment.

\section{LIGHT}

LIGHT (lymphotoxin-like inducible protein that competes with glycoprotein D for binding herpesvirus entry mediator on T cell, TNFSF14), ligand for the lymphotoxin beta receptor (LT $\beta$ R, TNFRSF3), and the herpesvirus entry mediator (HVEM; TNFRSF14) are expressed mostly on activated T cells, although they were found also on monocytes, granulocytes, and immature dendritic cells $[173,174]$. LT $\beta \mathrm{R}$ and HVEM receptors do not contain the death domain; therefore they are considered to be involved in prosurvival signalling [167]. Indeed, interaction between LIGHT and HVEM was found to enhance proliferation and effector functions of CD8(+) cytotoxic T cells [25], stimulate expansion of CD4(+) helper T cells, and promote their differentiation into Th1 cells [28].

Several studies indicate that LIGHT contributes to the development of intestinal inflammation. Transgenic mice with elevated expression of LIGHT spontaneously develop colitis [175]. Adoptive transfer of mesenteric lymph node cells expressing LIGHT into immunodeficient RAG-/- mice resulted in Thl-mediated intestinal inflammation dependent on both LIGHT receptors (LT $\beta$ R and HVEM) [49]. Furthermore, induction of colitis in mice by DSS resulted in strong upregulation of LIGHT mRNA in colon mucosa, whereas LIGHT-deficient mice showed significantly reduced symptoms of DSS-induced colon inflammation [176]. 
The pathological role of LIGHT in human IBD has been hardly investigated, although in IBD patients upregulation of LIGHT mRNA in inflamed intestinal mucosa when compared to noninflamed areas has been demonstrated [37]. Blockade of LIGHT as a way of IBD treatment has not been tested in clinical settings, although administration of antiLIGHT antibodies reduced symptoms of DSS-induced colon inflammation in mice [176].

\section{DcR3}

DcR3, soluble receptor for TL1A, FasL, and LIGHT, is a member of the TNF receptor superfamily that does not contain the transmembrane domain $[127,136]$. As a soluble receptor, it inhibits the interaction between its ligands and their membrane-bound receptors, thus suppressing their biological activity. Elevated expression of DcR3 was detected in inflamed mucosa and serum of CD and UC patients [177179]. The biological significance of this phenomenon remains unclear, although DcR3 is thought to play a protective role in IBD. For example, Funke et al. [179] showed that DcR3, acting as a soluble decoy receptor, limited the bioavailability of FasL and protected intestinal epithelial cells from FasLmediated apoptosis. In a similar way, DcR3 may also prevent the proinflammatory effect exerted by TL1A; thus, it has been proposed that upregulation of DcR3 expression during intestinal inflammation may have a compensatory, protective effect [45].

\section{TRAIL}

Certain reports indicate that another member of the TNF superfamily, TRAIL (TNF-related apoptosis inducing ligand, TNFSF10), expressed in a large variety of tissues including intestines may be involved in the pathogenesis of IBD [159]. Similarly to TNF, TRAIL is able to induce apoptosis and can also activate the prosurvival transcription factor NF- $\kappa$ B. Five receptors of TRAIL have been identified to date. TRAILR1 (TNFRSF10A; DR4) and TRAIL-R2 (TNFRSF-10B; DR5) contain the death domain in their cytoplasmic fragments and are involved in functional TRAIL signalling [128]. Other molecules, TRAIL-R3 (TNFRSF10C; DcR1) without the death domain and TRAIL-R4 (TNFRSF10D; DcR2) with defective death domain and soluble osteoprotegerin (OPG, TNFRSF11B), are considered to be decoy receptors [167].

Expression of TRAIL was found to be downregulated in intestinal epithelial cells of IBD patients [180]; however, it was significantly elevated in mononuclear cells of the resected inflamed mucosa in both CD and UC patients with highly active, steroid-refractory disease $[38,180]$.

Even though the exact role of TRAIL in IBD pathogenesis remains undefined, the available data suggest that TRAILexpressing mononuclear cells present in lamina propria disrupt the integrity of intestinal epithelium by inducing apoptosis of enterocytes. This notion was supported by an ex vivo study on ileal organ cultures which revealed that under inflammatory conditions TRAIL became a potent inducer of apoptosis in intestinal epithelial cells [38]. TRAIL is also a potent mediator of apoptotic death of intestinal fibroblasts in fibrostenosing intestinal areas in CD. Since collagen deposits and fibroblast proliferation are factors contributing to the development of strictures and fistulas, relatively common in CD patients, TRAIL can be involved also in tissue remodelling associated with CD [50].

\section{TWEAK}

TWEAK (TNF-like weak inducer of apoptosis, TNFSF12) acts through its receptor Fn14 (TNFRSF12; TWEAK-R) and has multiple biological activities, including stimulation of cell growth, induction of proinflammatory cytokines, and, in certain experimental settings, induction of apoptosis. TWEAK protein is expressed mostly in immune cells such as T cells, macrophages, or dendritic cells, although it was found also in nonhematopoietic cell types like astrocytes or endothelial cells [181]. Expression of TWEAK receptor, Fn14, was found on a variety of cells, including cells of intestinal mucosa. Fn14 does not contain the death domain and its stimulation with TWEAK results in activation of the transcription factor NF- $\kappa \mathrm{B}[181,182]$.

There are very few studies concerning the role of TWEAK in IBD pathogenesis; however in the intestinal mucosa of UC patients messenger RNA levels of IL-13, TWEAK, and Fn14 increased with disease activity [39]. TWEAK deficiency or reduction of its biological activity by anti-TWEAK monoclonal antibodies reduced expression of proinflammatory cytokines, neutrophil, and macrophage infiltration decreasing severity of trinitrobenzenesulfonic (TNBS) acid-induced colitis in mice [51]. Furthermore, even though TWEAK alone did not induce damage or apoptosis of intestinal epithelial cells, it was required, together with Fn14 and TNF, for IL-13induced activation of caspase- 3 in enterocytes isolated from $\gamma$-irradiated mice [39]. In vitro studies on rhabdomyosarcoma cell line Kym-1 showed that TWEAK upregulated expression of transmembrane TNF which in turn induced cell apoptosis via TNFR1 [183]. Furthermore, TWEAK stimulation synergistically enhanced TNFR1-mediated apoptotic cell death of Kym-1 cells [183] which can be explained by the fact that TWEAK induces translocation of antiapoptotic adaptor protein TRAF2 from the TNFR1 signalling complex, enhancing proapoptotic signalling of this receptor [184]. The question whether these mechanisms are active also in vivo in intestinal epithelium has not yet been studied.

\section{Conclusions}

Members of the TNF superfamily contribute to the pathogenesis of IBD in two ways. (i) They disrupt the integrity of intestinal epithelium by altering the arrangement of adhesion proteins in enterocytes (TNF), inducing apoptotic death of enterocytes (TNF, FasL, TRAIL, and TWEAK), and/or (ii) they promote the proinflammatory activity of mucosainfiltrating mononuclear cells (TNF, TL1A, LIGHT, TWEAK, and possibly FasL) and affect the activity of regulatory T cells and regulatory macrophages (Figure 1). 


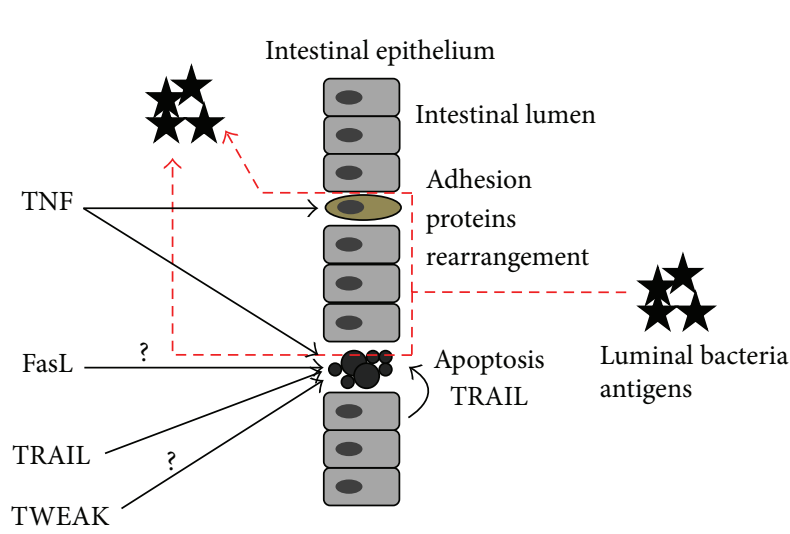

(a)
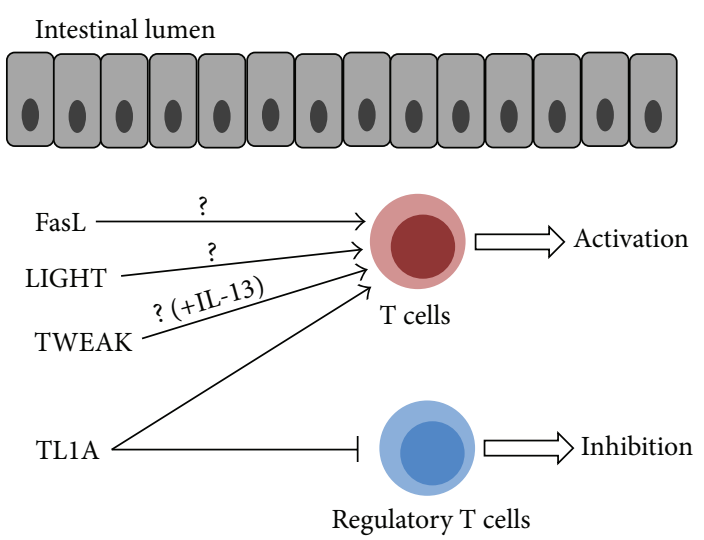

(b)

FIGURE 1: Two major mechanisms which implicate the molecules belonging to the TNFSF in the pathomechanisms of IBD. (a) Disruption of intestinal epithelium integrity allows luminal bacterial antigens to cross the epithelial barrier and migrate into the intestinal mucosa where they elicit immune responses. (b) Activation of mucosa-infiltrating T lymphocytes.

TNF superfamily members have attracted large attention as potential therapeutic targets in IBD treatment. Currently, however, the only TNFSF member targeted in clinical treatment of IBD is TNF. Another promising target, although still not tested in clinical trials, is TL1A which appears to be one of the key factors regulating the inflammatory pathways in IBD. The other members of TNF superfamily involved in IBD pathogenesis (FasL, LIGHT, TRAIL, and TWEAK) still require more in-depth studies to clearly define their function in intestinal inflammation. It has to be emphasized, however, that inflammatory injury of intestinal mucosa, a major feature of IBD, is mediated not only by the cross talk between various TNF superfamily members and their respective receptors since it results from the interactions of many cell types and inflammatory mediators which trigger multiple intracellular signalling pathways. Therefore, despite great therapeutic progress achieved in the treatment of Crohn's disease and ulcerative colitis by targeting TNF with various types of antibodies, further detailed studies are necessary to better understand the pathomechanisms of tissue injury in IBD aimed at defining more specific therapeutic targets.

\section{Abbreviations}

AICD: Activation-induced cell death

AP-1: Activator protein 1

CD: Crohn's disease

CHX: Cycloheximide

DcR3: Soluble decoy receptor 3

DD: Death domain

DNBS: Dinitrobenzenesulfonic acid

DR3: Death receptor 3

DSS: Dextran sodium sulphate

EGFR: Epidermal growth factor receptor

EMA: European Medicines Agency

FADD: Fas-associated death domain

FDA: Food and Drug Administration

GI: Gastrointestinal
IBD: Inflammatory bowel disease

IFN- $\gamma$ : Interferon gamma

IL: Interleukin

iNOS: Inducible nitric oxide synthase

LIGHT: Lymphotoxin-like inducible protein that competes with glycoprotein D for binding herpesvirus entry mediator on $\mathrm{T}$ cell

LPS: Lipopolysaccharide

MCP-1: Monocyte chemotactic protein 1

MLC: $\quad$ Myosin light chain

MLCK: Myosin light chain kinase

MMP: $\quad$ Matrix metalloproteinase

mRNA: Messenger RNA

NF- $\kappa$ B: $\quad$ Nuclear factor kappa B

NK: $\quad$ Natural killer

PBMCs: Peripheral blood mononuclear cells

TJ: $\quad$ Tight junction

TL1A: TNF-like protein 1A

TLR: Toll-like receptor

TNBS: Trinitrobenzenesulfonic acid

TNF: Tumour necrosis factor

TNFR1: TNF receptor 1

TNFR2: TNF receptor 2

TNFSF: Tumour necrosis factor superfamily

TRADD: TNF receptor-associated death domain

TRAF: Tumour necrosis factor receptor-associated protein

TRAIL: TNF-related apoptosis inducing ligand

TWEAK: TNF-like weak inducer of apoptosis

UC: $\quad$ Ulcerative colitis

VEGI: Vascular endothelial growth inhibitor.

\section{Conflict of Interests}

The authors declare that there is no conflict of interests regarding the publication of this paper. 


\section{Acknowledgment}

The preparation of this review has been supported by the Polish National Science Centre Grant 2011/01/B/NZ5/01358.

\section{References}

[1] W. Strober, I. Fuss, and P. Mannon, "The fundamental basis of inflammatory bowel disease," Journal of Clinical Investigation, vol. 117, no. 3, pp. 514-521, 2007.

[2] N. A. Molodecky and G. G. Kaplan, "Environmental risk factors for inflammatory bowel disease," Gastroenterology and Hepatology, vol. 6, no. 5, pp. 339-346, 2010.

[3] T. W. Hand, L. M. Dos Santos, N. Bouladoux et al., "Acute gastrointestinal infection induces long-lived microbiota-specific $\mathrm{T}$ cell responses," Science, vol. 337, no. 6101, pp. 1553-1556, 2012.

[4] L. Halme, P. Paavola-Sakki, U. Turunen, M. Lappalainen, M. Färkkilä, and K. Kontula, "Family and twin studies in inflammatory bowel disease," World Journal of Gastroenterology, vol. 12, no. 23, pp. 3668-3672, 2006.

[5] E. O. Glocker, D. Kotlarz, K. Boztug et al., "Inflammatory bowel disease and mutations affecting the interleukin-10 receptor," New England Journal of Medicine, vol. 361, no. 21, pp. 2033-2045, 2009.

[6] K. Yamazaki, D. McGovern, J. Ragoussis et al., "Single nucleotide polymorphisms in TNFSF15 confer susceptibility to Crohn's disease," Human Molecular Genetics, vol. 14, no. 22, pp. 3499-3506, 2005.

[7] S. Maeda, L. Hsu, H. Liu et al., "Nod2 mutation in Crohn's disease potentiates NF- $\kappa \mathrm{B}$ activity and IL- $1 \beta$ processing," Science, vol. 307 , no. 5710 , pp. 734-738, 2005.

[8] J. Hampe, A. Franke, P. Rosenstiel et al., "A genome-wide association scan of nonsynonymous SNPs identifies a susceptibility variant for Crohn disease in ATG16L1," Nature Genetics, vol. 39, no. 2, pp. 207-211, 2007.

[9] M. Parkes, J. C. Barrett, N. J. Prescott et al., "Sequence variants in the autophagy gene IRGM and multiple other replicating loci contribute to Crohn's disease susceptibility," Nature Genetics, vol. 39, no. 7, pp. 830-832, 2007.

[10] Z. Lin, L. Poritz, A. Franke et al., "Genetic association of DLG5 R30Q with familial and sporadic inflammatory bowel disease in men," Disease Markers, vol. 27, no. 5, pp. 193-201, 2009.

[11] S. Brand, "Crohn's disease: Thl, Thl7 or both? The change of a paradigm: new immunological and genetic insights implicate Th17 cells in the pathogenesis of Crohn's disease," Gut, vol. 58, no. 8, pp. 1152-1167, 2009.

[12] G. Bamias, G. Kaltsa, and S. D. Ladas, "Cytokines in the pathogenesis of ulcerative colitis," Discovery Medicine, vol. 11, no. 60, pp. 459-467, 2011.

[13] J. Šventoraityte, A. Žvirbliene, G. Kiudelis et al., "Immune system alterations in patients with inflammatory bowel disease during remission," Medicina, vol. 44, no. 1, pp. 27-33, 2008.

[14] S. Pak, N. Holland, E. A. Garnett et al., "Cytokine profiles in peripheral blood of children and adults with Crohn disease," Journal of Pediatric Gastroenterology and Nutrition, vol. 54, no. 6, pp. 769-775, 2012.

[15] N. Holland, J. Dong, E. Garnett et al., "Reduced intracellular T-helper 1 interferon-gamma in blood of newly diagnosed children with Crohn's disease and age-related changes in Th1/Th2 cytokine profiles," Pediatric Research, vol. 63, no. 3, pp. 257-262, 2008.
[16] I. J. Fuss and W. Strober, "The role of IL-13 and NK T cells in experimental and human ulcerative colitis," Mucosal Immunology, vol. 1, supplement 1, pp. S31-S33, 2008.

[17] C. J. Oliphant, J. L. Barlow, and A. N. J. Mckenzie, "Insights into the initiation of type 2 immune responses," Immunology, vol. 134, no. 4, pp. 378-385, 2011.

[18] F. Heller, A. Fromm, A. H. Gitter, J. Mankertz, and J.-D. Schulzke, "Epithelial apoptosis is a prominent feature of the epithelial barrier disturbance in intestinal inflammation: effect of pro-inflammatory interleukin-13 on epithelial cell function," Mucosal Immunology, vol. 1, supplement 1, pp. S58-S61, 2008.

[19] P. J. Mannon, R. L. Hornung, Z. Yang et al., "Suppression of inflammation in ulcerative colitis by interferon- $\beta$-la is accompanied by inhibition of IL-13 production," Gut, vol. 60 , no. 4, pp. 449-455, 2011.

[20] B. B. Aggarwal, S. C. Gupta, and J. H. Kim, "Historical perspectives on tumor necrosis factor and its superfamily: 25 years later, a golden journey," Blood, vol. 119, no. 3, pp. 651-665, 2012.

[21] B. B. Aggarwal, "Signalling pathways of the TNF superfamily: a double-edged sword," Nature Reviews Immunology, vol. 3, no. 9, pp. 745-756, 2003.

[22] R. H. Arch, R. W. Gedrich, and C. B. Thompson, "Tumor necrosis factor receptor-associated factors (TRAFs) — a family of adapter proteins that regulates life and death," Genes and Development, vol. 12, no. 18, pp. 2821-2830, 1998.

[23] R. Atreya, M. Zimmer, B. Bartsch et al., "Antibodies against tumor necrosis factor (TNF) induce T-cell apoptosis in patients with inflammatory bowel diseases via TNF receptor 2 and intestinal CD14 + macrophages," Gastroenterology, vol. 141, no. 6, pp. 2026-2038, 2011.

[24] H. Wajant, K. Pfizenmaier, and P. Scheurich, "Tumor necrosis factor signaling," Cell Death and Differentiation, vol. 10, no. 1, pp. 45-65, 2003.

[25] T. H. Watts, "TNF/TNFR family members in costimulation of T cell responses," Annual Review of Immunology, vol. 23, pp. 2368, 2005.

[26] M. Croft, "The role of TNF superfamily members in T-cell function and diseases," Nature Reviews Immunology, vol. 9, no. 4, pp. 271-285, 2009.

[27] M. A. Nolte, R. W. Van Olffen, K. P. J. M. Van Gisbergen, and R. A. W. Van Lier, "Timing and tuning of CD27-CD70 interactions: the impact of signal strength in setting the balance between adaptive responses and immunopathology," Immunological Reviews, vol. 229, no. 1, pp. 216-231, 2009.

[28] C. Wang, G. H. Lin, A. J. McPherson, and T. H. Watts, "Immune regulation by $4-1 \mathrm{BB}$ and $4-1 \mathrm{BBL}$ : complexities and challenges," Immunological Reviews, vol. 229, no. 1, pp. 192-215, 2009.

[29] M. Croft, T. So, W. Duan, and P. Soroosh, "The significance of OX40 and OX40L to T-cell biology and immune disease," Immunological Reviews, vol. 229, no. 1, pp. 173-191, 2009.

[30] B. P. Pappu, A. Borodovsky, T. S. Zheng et al., “TL1A-DR3 interaction regulates Th17 cell function and Th17-mediated autoimmune disease," Journal of Experimental Medicine, vol. 205, no. 5, pp. 1049-1062, 2008.

[31] Z. Kmiec, "Cytokines in inflammatory bowel disease," Archivum Immunologiae et Therapia Experimentalis, vol. 46, pp. 143-155, 1998.

[32] G. Bamias, D. Corridoni, T. T. Pizarro, and F. Cominelli, "New insights into the dichotomous role of innate cytokines in gut homeostasis and inflammation," Cytokine, vol. 59, no. 3, pp. 451459, 2012. 
[33] F. Meylan, A. C. Richard, and R. M. Siegel, "TL1A and DR3, a TNF family ligand-receptor pair that promotes lymphocyte costimulation, mucosal hyperplasia, and autoimmune inflammation," Immunological Reviews, vol. 244, no. 1, pp. 188-196, 2011.

[34] H. Ueyama, T. Kiyohara, N. Sawada et al., "High Fas ligand expression on lymphocytes in lesions of ulcerative colitis," Gut, vol. 43, no. 1, pp. 48-55, 1998.

[35] M. Yukawa, M. Iizuka, Y. Horie et al., "Systemic and local evidence of increased Fas-mediated apoptosis in ulcerative colitis," International Journal of Colorectal Disease, vol. 17, no. 2, pp. 70-76, 2002.

[36] H. S. P. Souza, C. J. A. Tortori, M. T. L. Castelo-Branco et al., "Apoptosis in the intestinal mucosa of patients with inflammatory bowel disease: evidence of altered expression of FasL and perforin cytotoxic pathways,' International Journal of Colorectal Disease, vol. 20, no. 3, pp. 277-286, 2005.

[37] O. Cohavy, J. Zhou, C. F. Ware, and S. R. Targan, "LIGHT is constitutively expressed on $\mathrm{T}$ and NK cells in the human gut and can be induced by CD2-mediated signaling," Journal of Immunology, vol. 174, no. 2, pp. 646-653, 2005.

[38] B. Begue, H. Wajant, J. Bambou et al., "Implication of TNFrelated apoptosis-inducing ligand in inflammatory intestinal epithelial lesions," Gastroenterology, vol. 130, no. 7, pp. 19621974, 2006.

[39] R. Kawashima, Y. I. Kawamura, T. Oshio et al., "Interleukin13 damages intestinal mucosa via TWEAK and Fn14 in MiceA pathway associated with ulcerative colitis," Gastroenterology, vol. 141, no. 6, pp. e2118-e2119, 2011.

[40] L. Cabal-Hierro and P. S. Lazo, "Signal transduction by tumor necrosis factor receptors," Cellular Signalling, vol. 24, no. 6, pp. 1297-1305, 2012.

[41] R. M. Locksley, N. Killeen, and M. J. Lenardo, "The TNF and TNF receptor superfamilies: integrating mammalian biology," Cell, vol. 104, no. 4, pp. 487-501, 2001.

[42] D. L. Faustman and M. Davis, "TNF receptor 2 and disease: autoimmunity and regenerative medicine," Frontiers in Immunology, vol. 4, p. 478, 2013.

[43] M. Leppkes, M. Roulis, M. F. Neurath, G. Kollias, and C. Becker, "The pleiotropic functions of TNF-alpha in the regulation of the intestinal epithelial response to inflammation," International Immunology, 2014.

[44] F. Van Hauwermeiren, M. Armaka, N. Karagianni et al., "Safe TNF-based antitumor therapy following p55TNFR reduction in intestinal epithelium," Journal of Clinical Investigation, vol. 123, no. 6, pp. 2590-2603, 2013.

[45] G. Bamias, L. G. Jia, and F. Cominelli, "The tumor necrosis factor-like cytokine 1A/death receptor 3 cytokine system in intestinal inflammation," Current Opinion in Gastroenterology, vol. 29, no. 6, pp. 597-602, 2013.

[46] T. H. Schreiber and E. R. Podack, "Immunobiology of TNFSF15 and TNFRSF25," Immunologic Research, vol. 57, no. 1-3, pp. 3-11, 2013.

[47] M. Lettau, M. Paulsen, D. Kabelitz, and O. Janssen, "FasL expression and reverse signalling," Results and Problems in Cell Differentiation, vol. 49, pp. 49-61, 2009.

[48] L. Chen, S. Park, J. R. Turner, and M. E. Peter, "Cell death in the colonic epithelium during inflammatory bowel diseases: CD95/Fas and beyond," Inflammatory Bowel Diseases, vol. 16, no. 6, pp. 1071-1076, 2010.
[49] J. Wang, R. A. Anders, Y. Wang et al., "The critical role of LIGHT in promoting intestinal inflammation and Crohn's disease," Journal of Immunology, vol. 174, no. 12, pp. 8173-8182, 2005.

[50] C. Reenaers, N. Franchimont, C. Oury et al., "Sensitivity of intestinal fibroblasts to TNF-related apoptosis-inducing ligandmediated apoptosis in Crohn's disease," Scandinavian Journal of Gastroenterology, vol. 43, no. 11, pp. 1334-1345, 2008.

[51] T. Dohi, A. Borodovsky, P. Wu et al., “TWEAK/Fn14 pathway: a nonredundant role in intestinal damage in mice through a TWEAK/intestinal epithelial cell axis," Gastroenterology, vol. 136, no. 3, pp. 912-923, 2009.

[52] S. H. Murch, V. A. Lamkin, M. O. Savage, J. A. WalkerSmith, and T. T. MacDonald, "Serum concentrations of tumour necrosis factor $\alpha$ in childhood chronic inflammatory bowel disease," Gut, vol. 32, no. 8, pp. 913-917, 1991.

[53] S. Dionne, J. Hiscott, I. D'Agata, A. Duhaime, and E. G. Seidman, "Quantitative PCR analysis of TNF- $\alpha$ and IL- $1 \beta$ mRNA levels in pediatric IBD mucosal biopsies," Digestive Diseases and Sciences, vol. 42, no. 7, pp. 1557-1566, 1997.

[54] R. Matsuda, T. Koide, C. Tokoro et al., "Quantitive cytokine mRNA expression profiles in the colonic mucosa of patients with steroid Naïve ulcerative colitis during active and quiescent disease," Inflammatory Bowel Diseases, vol. 15, no. 3, pp. 328334, 2009.

[55] D. Owczarek, D. Cibor, M. K. Głowacki, A. Cieśla, and P. Mach, "TNF- $\alpha$ and soluble forms of TNF receptors 1 and 2 in the serum of patients with Crohn's disease and ulcerative colitis," Polskie Archiwum Medycyny Wewnetrznej, vol. 122, no. 12, pp. 616-623, 2012.

[56] M. Maeda, N. Watanabe, H. Neda et al., "Serum tumor necrosis factor activity in inflammatory bowel disease," Immunopharmacology and Immunotoxicology, vol. 14, no. 3, pp. 451-461, 1992.

[57] S. H. Murch, C. P. Braegger, J. A. Walker-Smith, and T. T. MacDonald, "Location of tumour necrosis factor $\alpha$ by immunohistochemistry in chronic inflammatory bowel disease," Gut, vol. 34, no. 12, pp. 1705-1709, 1993.

[58] C. Stevens, G. Walz, C. Singaram et al., "Tumor necrosis factor$\alpha$, interleukin- $1 \beta$, and interleukin- 6 expression in inflammatory bowel disease," Digestive Diseases and Sciences, vol. 37, no. 6, pp. 818-826, 1992.

[59] J. S. Hyams, W. R. Treem, E. Eddy, N. Wyzga, and R. E. Moore, "Tumor necrosis factor- $\alpha$ is not elevated in children with inflammatory bowel disease," Journal of Pediatric Gastroenterology and Nutrition, vol. 12, no. 2, pp. 233-236, 1991.

[60] C. Perrier, G. De Hertogh, J. Cremer et al., "Neutralization of membrane TNF, but not soluble TNF, is crucial for the treatment of experimental colitis," Inflammatory Bowel Diseases, vol. 19, no. 2, pp. 246-253, 2013.

[61] E. Mizoguchi, A. Mizoguchi, H. Takedatsu et al., "Role of tumor necrosis factor receptor 2 (TNFR2) in colonic epithelial hyperplasia and chronic intestinal inflammation in mice," Gastroenterology, vol. 122, no. 1, pp. 134-144, 2002.

[62] M. H. Holtmann, E. Douni, M. Schutz et al., "Tumor necrosis factor-receptor 2 is up-regulated on lamina propria $\mathrm{T}$ cells in Crohn's disease and promotes experimental colitis in vivo," European Journal of Immunology, vol. 32, no. 11, pp. 3142-3151, 2002.

[63] T. Y. Ma, G. K. Iwamoto, N. T. Hoa et al., "TNF- $\alpha$-induced increase in intestinal epithelial tight junction permeability requires NF- $\kappa \mathrm{B}$ activation," American Journal of PhysiologyGastrointestinal and Liver Physiology, vol. 286, no. 3, pp. G367G376, 2004. 
[64] T. Fréour, A. Jarry, K. Bach-Ngohou et al., “TACE inhibition amplifies TNF- $\alpha$-mediated colonic epithelial barrier disruption," International Journal of Molecular Medicine, vol. 23, no. 1, pp. 41-48, 2009.

[65] F. Wang, B. T. Schwarz, W. V. Graham et al., "IFN- $\gamma$-induced TNFR2 expression is required for TNF-dependent intestinal epithelial barrier dysfunction," Gastroenterology, vol. 131, no. 4, pp. 1153-1163, 2006.

[66] S. Rose-John, "ADAM17, shedding, TACE as therapeutic targets," Pharmacological Research, vol. 71, pp. 19-22, 2013.

[67] A. Cesaro, A. Abakar-Mahamat, P. Brest et al., "Differential expression and regulation of ADAM17 and TIMP3 in acute inflamed intestinal epithelia," American Journal of PhysiologyGastrointestinal and Liver Physiology, vol. 296, no. 6, pp. G1332G1343, 2009.

[68] E. Franzè, R. Caruso, C. Stolfi et al., "High expression of the "A disintegrin and metalloprotease" 19 (ADAM19), a sheddase for TNF-a in the mucosa of patients with inflammatory bowel diseases," Inflammatory Bowel Diseases, vol. 19, no. 3, pp. 501511, 2013.

[69] R. E. Vandenbroucke, E. Dejonckheere, F. Van Hauwermeiren et al., "Matrix metalloproteinase 13 modulates intestinal epithelial barrier integrity in inflammatory diseases by activating TNF," EMBO Molecular Medicine, vol. 5, no. 7, pp. 932-948, 2013.

[70] L. Su, S. C. Nalle, L. Shen et al., "TNFR2 activates mlckdependent tight junction dysregulation to cause apoptosismediated barrier loss and experimental colitis," Gastroenterology, vol. 145, no. 2, pp. 407-415, 2013.

[71] A. M. Marchiando, L. Shen, W. V. Graham et al., "The epithelial barrier is maintained by in vivo tight junction expansion during pathologic intestinal epithelial shedding," Gastroenterology, vol. 140, no. 4, pp. 1208-1218, 2011.

[72] T. Goretsky, R. Dirisina, P. Sinh et al., "P53 mediates TNFinduced epithelial cell apoptosis in IBD," American Journal of Pathology, vol. 181, no. 4, pp. 1306-1315, 2012.

[73] K. E. Cunningham and J. R. Turner, "Myosin light chain kinase: pulling the strings of epithelial tight junction function," Annals of the New York Academy of Sciences, vol. 1258, no. 1, pp. 34-42, 2012.

[74] S. A. Blair, S. V. Kane, D. R. Clayburgh, and J. R. Turner, "Epithelial myosin light chain kinase expression and activity are upregulated in inflammatory bowel disease," Laboratory Investigation, vol. 86, no. 2, pp. 191-201, 2006.

[75] T. Yamaoka, F. Yan, H. Cao et al., "Transactivation of EGF receptor and ErbB2 protects intestinal epithelial cells from TNF-induced apoptosis," Proceedings of the National Academy of Sciences of the United States of America, vol. 105, no. 33, pp. 11772-11777, 2008.

[76] S. S. Hobbs, J. A. Goettel, D. Liang et al., "TNF transactivation of EGFR stimulates cytoprotective COX-2 expression in gastrointestinal epithelial cells," American Journal of PhysiologyGastrointestinal and Liver Physiology, vol. 301, no. 2, pp. G220G229, 2011.

[77] K. Xu, L. Wang, and H. K. Shu, "COX-2 overexpression increases malignant potential of human glioma cells through Id1," Oncotarget, vol. 5, no. 5, pp. 1241-1252, 2014.

[78] M. Lukas, "Inflammatory bowel disease as a risk factor for colorectal cancer," Digestive Diseases, vol. 28, no. 4-5, pp. 619624, 2010

[79] I. Pache, G. Rogler, and C. Felley, "TNF- $\alpha$ blockers in inflammatory bowel diseases: practical consensus recommendations and a user's guide," Swiss Medical Weekly, vol. 139, no. 19-20, pp. 278-287, 2009.

[80] E. G. Boyce, J. Halilovic, and O. Stan-Ugbene, "Golimumab: review of the efficacy and tolerability of a recently approved tumor necrosis factor- $\alpha$ inhibitor," Clinical Therapeutics, vol. 32, no. 10, pp. 1681-1703, 2010.

[81] J. Dretzke, R. Edlin, J. Round et al., "A systematic review and economic evaluation of the use of tumour necrosis factor-alpha (TNF- $\alpha$ ) inhibitors, adalimumab and infliximab, for crohn's disease," Health Technology Assessment, vol. 15, no. 6, pp. 1-250, 2011.

[82] O. H. Nielsen, J. B. Seidelin, L. K. Munck, and G. Rogler, "Use of biological molecules in the treatment of inflammatory bowel disease," Journal of Internal Medicine, vol. 270, no. 1, pp. 15-28, 2011.

[83] M. M. Lawson, A. G. Thomas, and A. K. Akobeng, "Tumour necrosis factor alpha blocking agents for induction of remission in ulcerative colitis," Cochrane Database of Systematic Reviews, vol. 3, Article ID CD005112, 2006.

[84] S. M. Wilhelm, K. A. McKenney, K. N. Rivait, and P. B. KalePradhan, "A review of infliximab use in ulcerative colitis," Clinical Therapeutics, vol. 30, no. 2, pp. 223-230, 2008.

[85] W. Reinisch, W. J. Sandborn, D. W. Hommes et al., "Adalimumab for induction of clinical remission in moderately to severely active ulcerative colitis: results of a randomised controlled trial," Gut, vol. 60, no. 6, pp. 780-787, 2011.

[86] W. J. Sandborn, G. Van Assche, W. Reinisch et al., "Adalimumab induces and maintains clinical remission in patients with moderate-to-severe ulcerative colitis," Gastroenterology, vol. 142, no. 2, pp. 257-265, 2012.

[87] W. J. Sandborn, B. G. Feagan, C. Marano et al., "Subcutaneous golimumab induces clinical response and remission in patients with moderate-to-severe ulcerative colitis," Gastroenterology, vol. 146, no. 1, pp. 85-95, 2014.

[88] W. J. Sandborn, B. G. Feagan, C. Marano et al., "Subcutaneous golimumab maintains clinical response in patients with moderate-to-severe ulcerative colitis," Gastroenterology, vol. 146, no. 1, pp. 96.el-109.el, 2014.

[89] L. Peyrin-Biroulet, P. Deltenre, N. de Suray, J. Branche, W. J. Sandborn, and J. Colombel, "Efficacy and safety of tumor necrosis factor antagonists in Crohn's disease: meta-analysis of placebo-controlled trials," Clinical Gastroenterology and Hepatology, vol. 6, no. 6, pp. 644-653, 2008.

[90] O. H. Nielsen and M. A. Ainsworth, "Tumor necrosis factor inhibitors for inflammatory bowel disease," New England Journal of Medicine, vol. 369, no. 8, pp. 754-762, 2013.

[91] A. J. Yarur, M. T. Abreu, A. R. Deshpande et al., "Therapeutic drug monitoring in patients with inflammatory bowel disease," World Journal of Gastroenterology, vol. 20, no. 13, pp. 3475-3484, 2014.

[92] S. Danese, G. Fiorino, L. Peyrin-Biroulet et al., "Biological agents for moderately to severely active ulcerative colitis: a systematic review and network meta-analysis," Annals of Internal Medicine, vol. 160, no. 10, pp. 704-711, 2014.

[93] S. Ben-Horin, U. Kopylov, and Y. Chowers, "Optimizing antiTNF treatments in inflammatory bowel disease," Autoimmunity Reviews, vol. 126, no. 6, pp. 1593-1610, 2014.

[94] R. Altwegg and T. Vincent, "TNF blocking therapies and immunomonitoring in patients with inflammatory bowel disease," Mediators of Inflammation, vol. 2014, Article ID 172821, 7 pages, 2014. 
[95] G. R. Lichtenstein, "Comprehensive review: antitumor necrosis factor agents in inflammatory bowel disease and factors implicated in treatment response," Therapeutic Advances in Gastroenterology, vol. 6, no. 4, pp. 269-293, 2013.

[96] P. Campi, M. Benucci, M. Manfredi, and P. Demoly, "Hypersensitivity reactions to biological agents with special emphasis on tumor necrosis factor- $\alpha$ antagonists," Current Opinion in Allergy and Clinical Immunology, vol. 7, no. 5, pp. 393-403, 2007.

[97] A. Barbaud, F. Granel, J. Waton, and C. Poreaux, "How to manage hypersensitivity reactions to biological agents?" European Journal of Dermatology, vol. 21, no. 5, pp. 667-674, 2011.

[98] P. Deepak, D. J. Stobaugh, and E. D. Ehrenpreis, "Infectious complications of TNF-alpha inhibitor monotherapy versus combination therapy with immunomodulators in inflammatory bowel disease: analysis of the Food and Drug Administration Adverse Event Reporting System," Journal of Gastrointestinal and Liver Diseases, vol. 22, no. 3, pp. 269-276, 2013.

[99] P. Lozeron, C. Denier, C. Lacroix, and D. Adams, "Long-term course of demyelinating neuropathies occurring during tumor necrosis factor-a-blocker therapy," Archives of Neurology, vol. 66, no. 4, pp. 490-497, 2009.

[100] P. Deepak, D. J. Stobaugh, M. Sherid, H. Sifuentes, and E. D. Ehrenpreis, "Neurological events with tumour necrosis factor alpha inhibitors reported to the Food and Drug Administration Adverse Event Reporting System," Alimentary Pharmacology and Therapeutics, vol. 38, no. 4, pp. 388-396, 2013.

[101] G. Moris, "Inflammatory bowel disease: an increased risk factor for neurologic complications," World Journal of Gastroenterology, vol. 20, no. 5, pp. 1228-1237, 2014.

[102] G. Fiorino, S. Danese, B. Pariente, and M. Allez, "Paradoxical immune-mediated inflammation in inflammatory bowel disease patients receiving anti-TNF- $\alpha$ agents," Autoimmunity Reviews, vol. 13, no. 1, pp. 15-19, 2014.

[103] C. Tillack, L. M. Ehmann, M. Friedrich et al., "Anti-TNF antibody-induced psoriasiform skin lesions in patients with inflammatory bowel disease are characterised by interferongamma-expressing Th1 cells and IL-17A/IL-22-expressing Th17 cells and respond to anti-IL-12/IL-23 antibody treatment," Gut, vol. 63, no. 4, pp. 567-577, 2014.

[104] J. M. H. Van den Brande, H. Braat, G. R. Van den Brink et al., "Infliximab but not etanercept induces apoptosis in lamina propria T-lymphocytes from patients with Crohn's disease," Gastroenterology, vol. 124, no. 7, pp. 1774-1785, 2003.

[105] J. Mudter and M. F. Neurath, "Apoptosis of T cells and the control of inflammatory bowel disease: therapeutic implications," Gut, vol. 56, no. 2, pp. 293-303, 2007.

[106] C. Veltkamp, M. Anstaett, K. Wahl et al., "Apoptosis of regulatory $\mathrm{T}$ lymphocytes is increased in chronic inflammatory bowel disease and reversed by anti-TNF $\alpha$ treatment," Gut, vol. 60, no. 10, pp. 1345-1353, 2011.

[107] G. Boschetti, S. Nancey, F. Sardi, X. Roblin, B. Flourié, and D. Kaiserlian, "Therapy with anti-TNF $\alpha$ antibody enhances number and function of Foxp3+ regulatory T cells in inflammatory bowel diseases," Inflammatory Bowel Diseases, vol. 17, no. 1, pp. 160-170, 2011.

[108] A. C. Vos, M. E. Wildenberg, M. Duijvestein, A. P. Verhaar, G. R. Van Den Brink, and D. W. Hommes, "AntiTumor necrosis factor- $\alpha$ antibodies induce regulatory macrophages in an Fc region-dependent manner," Gastroenterology, vol. 140, no. 1, pp. 221-230, 2011.

[109] A. C. Vos, M. E. Wildenberg, I. Arijs et al., "Regulatory macrophages induced by infliximab are involved in healing in vivo and in vitro," Inflammatory Bowel Diseases, vol. 18, no. 3, pp. 401-408, 2012.

[110] R. F. Leal, N. Planell, R. Kajekar et al., "Identification of inflammatory mediators in patients with Crohn's disease unresponsive to anti-TNFalpha therapy," Gut, 2014.

[111] P. Suenaert, V. Bulteel, L. Lemmens et al., "Anti-tumor necrosis factor treatment restores the gut barrier in Crohn's disease," American Journal of Gastroenterology, vol. 97, no. 8, pp. 20002004, 2002.

[112] W. Fries, C. Muja, C. Crisafulli et al., "Infliximab and etanercept are equally effective in reducing enterocyte apoptosis in experimental colitis," International Journal of Medical Sciences, vol. 5, no. 4, pp. 169-180, 2008.

[113] A. Fischer, M. Gluth, U. Pape, B. Wiedenmann, F. Theuring, and D. C. Baumgart, "Adalimumab prevents barrier dysfunction and antagonizes distinct effects of TNF- $\alpha$ on tight junction proteins and signaling pathways in intestinal epithelial cells," American Journal of Physiology-Gastrointestinal and Liver Physiology, vol. 304, no. 11, pp. G970-G979, 2013.

[114] P. Eder, L. Lykowska-Szuber, I. Krela-Kazmierczak et al., "AntiTNF antibodies do not induce the apoptosis of lamina propria mononuclear cells in uninflamed intestinal tissue in patients with Crohn's disease," Folia Histochemica et Cytobiologica, vol. 51, pp. 239-243, 2013.

[115] P. Eder, L. Lykowska-Szuber, I. Krela-Kazmierczak, K. Stawczyk-Eder, M. Zabel, and K. Linke, "The influence of infliximab and adalimumab on the expression of apoptosisrelated proteins in lamina propria mononuclear cells and enterocytes in Crohn's disease-an immunohistochemical study," Journal of Crohn's and Colitis, vol. 7, no. 9, pp. 706-716, 2013.

[116] B. Scallon, A. Cai, N. Solowski et al., "Binding and functional comparisons of two types of tumor necrosis factor antagonists," Journal of Pharmacology and Experimental Therapeutics, vol. 301, no. 2, pp. 418-426, 2002.

[117] W. J. Sandborn, S. B. Hanauer, S. Katz et al., "Etanercept for active Crohn's disease: a randomized, double-blind, placebocontrolled trial," Gastroenterology, vol. 121, no. 5, pp. 1088-1094, 2001.

[118] T. S. Migone, J. Zhang, X. Luo et al., "TL1A is a TNF-like ligand for DR3 and TR6/DcR3 and functions as a T cell costimulator," Immunity, vol. 16, no. 3, pp. 479-492, 2002.

[119] L. J. Metheny-Barlow and L. Y. Li, "Vascular endothelial growth inhibitor (VEGI), an endogenous negative regulator of angiogenesis," Seminars in Ophthalmology, vol. 21, no. 1, pp. 49-58, 2006.

[120] L. J. Chew, H. Pan, J. Yu et al., "A novel secreted splice variant of vascular endothelial cell growth inhibitor," The FASEB Journal, vol. 16, no. 7, pp. 742-744, 2002.

[121] N. Zhang, A. J. Sanders, L. Ye et al., "Vascular endothelial growth inhibitor in human cancer (Review)," International Journal of Molecular Medicine, vol. 24, no. 1, pp. 3-8, 2009.

[122] L. Fang, B. Adkins, V. Deyev, and E. R. Podack, "Essential role of TNF receptor superfamily 25 (TNFRSF25) in the development of allergic lung inflammation," Journal of Experimental Medicine, vol. 205, no. 5, pp. 1037-1048, 2008.

[123] F. Meylan, T. S. Davidson, E. Kahle et al., "The TNF-family receptor DR3 is essential for diverse T cell-mediated inflammatory diseases," Immunity, vol. 29, no. 1, pp. 79-89, 2008.

[124] J. Zhang, X. Wang, H. Fahmi et al., "Role of TL1A in the pathogenesis of rheumatoid arthritis," Journal of Immunology, vol. 183, no. 8, pp. 5350-5357, 2009. 
[125] G. Bamias, C. Martin III, M. Marini et al., "Expression, localization, and functional activity of TL1A, a novel Th1polarizing cytokine in inflammatory bowel disease," Journal of Immunology, vol. 171, no. 9, pp. 4868-4874, 2003.

[126] J. L. Prehn, S. Mehdizadeh, C. J. Landers et al., "Potential role for TL1A, the new TNF-family member and potent costimulator of IFN- $\gamma$, in mucosal inflammation," Clinical Immunology, vol. 112, no. 1, pp. 66-77, 2004.

[127] S. Kim and L. Zhang, "Identification of naturally secreted soluble form of TL1A, a TNF-like cytokine," Journal of Immunological Methods, vol. 298, no. 1-2, pp. 1-8, 2005.

[128] J. L. Prehn, L. S. Thomas, C. J. Landers, Q. T. Yu, K. S. Michelsen, and S. R. Targan, "The T cell costimulator TL1A is induced by $\mathrm{F} c \gamma \mathrm{R}$ signaling in human monocytes and dendritic cells," Journal of Immunology, vol. 178, no. 7, pp. 4033-4038, 2007.

[129] T. Jin, F. Guo, S. Kim, A. Howard, and Y. Zhang, "X-ray crystal structure of TNF ligand family member TL1A at 2.1 Å," Biochemical and Biophysical Research Communications, vol. 364, no. 1, pp. 1-6, 2007.

[130] D. Q. Shih, L. Y. Kwan, V. Chavez et al., "Microbial induction of inflammatory bowel disease associated gene TL1A (TNFSF15) in antigen presenting cells," European Journal of Immunology, vol. 39, no. 11, pp. 3239-3250, 2009.

[131] A. M. Chinnaiyan, K. O'Rourke, G. Yu et al., "Signal transduction by DR3, a death domain-containing receptor related to TNFR-1 and CD95," Science, vol. 274, no. 5289, pp. 990-992, 1996.

[132] Y. J. Kang, W. J. Kim, H. U. Bae et al., "Involvement of TL1A and DR3 in induction of pro-inflammatory cytokines and matrix metalloproteinase-9 in atherogenesis," Cytokine, vol. 29, no. 5, pp. 229-235, 2005.

[133] K. A. Papadakis, J. L. Prehn, C. Landers et al., “TL1A synergizes with IL-12 and IL-18 to enhance IFN- $\gamma$ production in human T cells and NK cells," Journal of Immunology, vol. 172, no. 11, pp. 7002-7007, 2004.

[134] C. Cavallini, O. Lovato, A. Bertolaso et al., "The TNF-Family Cytokine TL1A Inhibits Proliferation of Human Activated B Cells," PLoS ONE, vol. 8, no. 4, Article ID e60136, 2013.

[135] K. A. Papadakis, D. Zhu, J. L. Prehn et al., "Dominant role for TL1A/DR3 pathway in IL-12 plus IL-18-induced IFN- $\gamma$ production by peripheral blood and mucosal CCR9+ T lymphocytes," Journal of Immunology, vol. 174, no. 8, pp. 4985-4990, 2005.

[136] C. R. Yang, S. L. Hsieh, C. M. Teng, F. Ho, W. Su, and W. Lin, "Soluble decoy receptor 3 induces angiogenesis by neutralization of TL1A, a cytokine belonging to tumor necrosis factor superfamily and exhibiting angiostatic action," Cancer Research, vol. 64, no. 3, pp. 1122-1129, 2004.

[137] L. Wen, L. Zhuang, X. Luo, and P. Wei, “TL1A-induced NF$\kappa \mathrm{B}$ activation and c-IAP2 production prevent DR3-mediated apoptosis in TF-1 cells," Journal of Biological Chemistry, vol. 278, no. 40, pp. 39251-39258, 2003.

[138] T. J. Slebioda, T. F. Rowley, J. R. Ferdinand et al., “Triggering of TNFRSF25 promotes CD8+ T-cell responses and anti-tumor immunity," European Journal of Immunology, vol. 41, no. 9, pp. 2606-2611, 2011.

[139] H. Takedatsu, K. S. Michelsen, B. Wei et al., “TL1A (TNFSF15) regulates the development of chronic colitis by modulating both T-helper 1 and T-helper 17 activation," Gastroenterology, vol. 135, no. 2, pp. 552-567, 2008.

[140] N. Kamada, T. Hisamatsu, H. Honda et al., "TL1A produced by lamina propria macrophages induces Thl and Th17 immune responses in cooperation with IL-23 in patients with Crohn's disease," Inflammatory Bowel Diseases, vol. 16, no. 4, pp. 568$575,2010$.

[141] S. F. Wu, T. M. Liu, Y. C. Lin et al., "Immunomodulatory effect of decoy receptor 3 on the differentiation and function of bone marrow-derived dendritic cells in nonobese diabetic mice: from regulatory mechanism to clinical implication," Journal of Leukocyte Biology, vol. 75, no. 2, pp. 293-306, 2004.

[142] T. L. Hsu, Y. C. Chang, S. J. Chen et al., "Modulation of dendritic cell differentiation and maturation by decoy receptor 3," Journal of Immunology, vol. 168, no. 10, pp. 4846-4853, 2002.

[143] F. Meylan, Y.-J. Song, I. Fuss et al., "The TNF-family cytokine TL1A drives IL-13-dependent small intestinal inflammation," Mucosal Immunology, vol. 4, no. 2, pp. 172-185, 2011.

[144] V. Y. Taraban, T. J. Slebioda, J. E. Willoughby et al., "Sustained TL1A expression modulates effector and regulatory T-cell responses and drives intestinal goblet cell hyperplasia," Mucosal Immunology, vol. 4, no. 2, pp. 186-196, 2011.

[145] S. Q. Khan, M. S. Tsai, T. H. Schreiber, D. Wolf, V. V. Deyev, and E. R. Podack, "Cloning, expression, and functional characterization of TL1A-Ig," Journal of Immunology, vol. 190, no. 4, pp. 1540-1550, 2013.

[146] Y. Kakuta, N. Ueki, Y. Kinouchi et al., "TNFSF15 transcripts from risk haplotype for Crohn's disease are overexpressed in stimulated T cells," Human Molecular Genetics, vol. 18, no. 6, pp. 1089-1098, 2009.

[147] K. S. Michelsen, L. S. Thomas, K. D. Taylor et al., "IBDassociated TL1A gene (TNFSFI5) haplotypes determine increased expression of TL1A protein," PLoS ONE, vol. 4, no. 3, Article ID e4719, 2009.

[148] S. Jin, J. Chin, S. Seeber et al., "TL1A/TNFSF15 directly induces proinflammatory cytokines, including $\mathrm{TNF} \alpha$, from CD3+CD161+ T cells to exacerbate gut inflammation," Mucosal Immunology, vol. 6, no. 5, pp. 886-899, 2013.

[149] O. Cohavy, D. Q. Shih, T. M. Doherty et al., "Cd161 defines effector $\mathrm{T}$ cells that express light and respond to Tlia-Dr3 signaling," European Journal of Microbiology and Immunology, vol. 1, no. 1, pp. 70-79, 2011.

[150] M. A. Kleinschek, K. Boniface, S. Sadekova et al., "Circulating and gut-resident human Th17 cells express CD161 and promote intestinal inflammation," Journal of Experimental Medicine, vol. 206, no. 3, pp. 525-534, 2009.

[151] W. Strober and I. J. Fuss, "Proinflammatory cytokines in the pathogenesis of inflammatory bowel diseases," Gastroenterology, vol. 140, no. 6, pp. 1756-1767, 2011.

[152] S. Tauzin, L. Debure, J. Moreau, and P. Legembre, "CD95mediated cell signaling in cancer: mutations and posttranslational modulations," Cellular and Molecular Life Sciences, vol. 69, no. 8, pp. 1261-1277, 2012.

[153] M. Lettau, M. Paulsen, H. Schmidt, and O. Janssen, "Insights into the molecular regulation of FasL (CD178) biology," European Journal of Cell Biology, vol. 90, no. 6-7, pp. 456-466, 2011.

[154] L. A. O’Reilly, L. Tai, L. Lee et al., "Membrane-bound Fas ligand only is essential for Fas-induced apoptosis," Nature, vol. 461, no. 7264, pp. 659-663, 2009.

[155] P. Moller, K. Koretz, F. Leithauser et al., "Expression of APO1 (CD95), a member of the NGF/TNF receptor superfamily, in normal and neoplastic colon epithelium," International Journal of Cancer, vol. 57, no. 3, pp. 371-377, 1994.

[156] P. Möller, H. Walczak, S. Riedl, J. Sträter, and P. H. Krammer, "Paneth cells express high levels of CD95 ligand transcripts: 
a unique property among gastrointestinal epithelia," American Journal of Pathology, vol. 149, no. 1, pp. 9-13, 1996.

[157] M. J. Pinkoski, T. Brunner, D. R. Green, and T. Lin, "Fas and Fas ligand in gut and liver," American Journal of PhysiologyGastrointestinal and Liver Physiology, vol. 278, no. 3, pp. G354G366, 2000.

[158] J. Strater, I. Wellisch, S. Riedl et al., "CD95 (APO-1/Fas)mediated apoptosis in colon epithelial cells: a possible role in ulcerative colitis," Gastroenterology, vol. 113, no. 1, pp. 160-167, 1997.

[159] J. Strater and P. Moller, "Expression and function of death receptors and their natural ligands in the intestine," Annals of the New York Academy of Sciences, vol. 915, pp. 162-170, 2000.

[160] J. B. Seidelin and O. H. Nielsen, "Attenuated apoptosis response to Fas-ligand in active ulcerative colitis," Inflammatory Bowel Diseases, vol. 14, no. 12, pp. 1623-1629, 2008.

[161] S. M. Park, L. Chen, M. Zhang, P. Ashton-Rickardt, J. R. Turner, and M. E. Peter, "CD95 is cytoprotective for intestinal epithelial cells in colitis," Inflammatory Bowel Diseases, vol. 16, no. 6, pp. 1063-1070, 2010.

[162] M. Merger, J. L. Viney, R. Borojevic et al., "Defining the roles of perforin, Fas/FasL, and tumour necrosis factor $\alpha$ in T cell induced mucosal damage in the mouse intestine," Gut, vol. 51, no. 2, pp. 155-163, 2002.

[163] I. Monteleone, G. Monteleone, D. Fina et al., "A functional role of flip in conferring resistance of Crohn's disease lamina propria lymphocytes to FAS-mediated apoptosis," Gastroenterology, vol. 130, no. 2, pp. 389-397, 2006.

[164] K. Ina, J. Itoh, K. Fukushima et al., "Resistance of Crohn's disease T cells to multiple apoptotic signals is associated with a Bcl-2/Bax mucosal imbalance," Journal of Immunology, vol. 163, no. 2, pp. 1081-1090, 1999.

[165] M. Boirivant, M. Marini, G. Di Felice et al., "Lamina propria T cells in Crohn's disease and other gastrointestinal inflammation show defective CD2 pathway-induced apoptosis," Gastroenterology, vol. 116, no. 3, pp. 557-565, 1999.

[166] A. Suzuki, K. Sugimura, K. Ohtsuka et al., "Fas/Fas ligand expression and characteristics of primed CD45RO+ T cells in the inflamed mucosa of ulcerative colitis," Scandinavian Journal of Gastroenterology, vol. 35, no. 12, pp. 1278-1283, 2000.

[167] T. Hehlgans and K. Pfeffer, "The intriguing biology of the tumour necrosis factor/tumour necrosis factor receptor superfamily: players, rules and the games," Immunology, vol. 115, no. 1, pp. 1-20, 2005.

[168] M. Paulsen, S. Valentin, B. Mathew et al., "Modulation of CD4+ T-cell activation by CD95 co-stimulation," Cell Death and Differentiation, vol. 18, no. 4, pp. 619-631, 2011.

[169] I. Suzuki and P. J. Fink, "Maximal proliferation of cytotoxic T lymphocytes requires reverse signaling through Fas ligand," Journal of Experimental Medicine, vol. 187, no. 1, pp. 123-128, 1998.

[170] I. Suzuki and P. J. Fink, "The dual functions of Fas ligand in the regulation of peripheral CD8+ and CD4+ T cells," Proceedings of the National Academy of Sciences of the United States of America, vol. 97, no. 4, pp. 1707-1712, 2000.

[171] I. Suzuki, S. Martin, T. E. Boursalian, C. Beers, and P. J. Fink, "Fas ligand costimulates the in vivo proliferation of CD8+ T cells," Journal of Immunology, vol. 165, no. 10, pp. 5537-5543, 2000.

[172] G. Shi, H. Luo, X. Wan, T. W. Salcedo, J. Zhang, and J. Wu, "Mouse $\mathrm{T}$ cells receive costimulatory signals from LIGHT, a TNF family member," Blood, vol. 100, no. 9, pp. 3279-3286, 2002.
[173] D. N. Mauri, R. Ebner, R. I. Montgomery et al., "LIGHT, a new member of the TNF superfamily, and lymphotoxin $\alpha$ are ligands for herpesvirus entry mediator," Immunity, vol. 8, no. 1, pp. 2130, 1998.

[174] Y. Zhai, R. Guo, T. Hsu et al., "LIGHT, a novel ligand for lymphotoxin $\beta$ receptor and TR2/HVEM induces apoptosis and suppresses in vivo tumor formation via gene transfer," Journal of Clinical Investigation, vol. 102, no. 6, pp. 1142-1151, 1998.

[175] R. B. Shaikh, S. Santee, S. W. Granger et al., "Constitutive expression of LIGHT on T cells leads to lymphocyte activation, inflammation, and tissue destruction," Journal of Immunology, vol. 167, no. 11, pp. 6330-6337, 2001.

[176] M. Jungbeck, B. Daller, J. Federhofer et al., "Neutralization of LIGHT ameliorates acute dextran sodium sulphate-induced intestinal inflammation," Immunology, vol. 128, no. 3, pp. 451458, 2009.

[177] G. Bamias, G. Kaltsa, S. I. Siakavellas et al., "Differential expression of the TL1A/DcR3 system of TNF/TNFR-like proteins in large vs. small intestinal Crohn's disease," Digestive and Liver Disease, vol. 44, no. 1, pp. 30-36, 2012.

[178] G. Bamias, G. Kaltsa, S. I. Siakavellas et al., "High intestinal and systemic levels of decoy receptor 3 (DcR3) and its ligand TL1A in active ulcerative colitis," Clinical Immunology, vol. 137, no. 2, pp. 242-249, 2010.

[179] B. Funke, F. Autschbach, S. Kim et al., "Functional characterisation of decoy receptor 3 in Crohn's disease," Gut, vol. 58, no. 4, pp. 483-491, 2009.

[180] S. Brost, R. Koschny, J. Sykora et al., "Differential expression of the TRAIL/TRAIL-receptor system in patients with inflammatory bowel disease," Pathology Research and Practice, vol. 206, no. 1, pp. 43-50, 2010.

[181] S. R. Wiley and J. A. Winkles, "TWEAK, a member of the TNF superfamily, is a multifunctional cytokine that binds the TweakR/Fn14 receptor," Cytokine and Growth Factor Reviews, vol. 14, no. 3-4, pp. 241-249, 2003.

[182] J. S. Michaelson, N. Wisniacki, L. C. Burkly, and C. Putterman, "Role of TWEAK in lupus nephritis: a bench-to-bedside review," Journal of Autoimmunity, vol. 39, no. 3, pp. 130-142, 2012.

[183] P. Schneider, R. Schwenzer, E. Haas et al., "TWEAK can induce cell death via endogenous TNF and TNF receptor 1," European Journal of Immunology, vol. 29, no. 6, pp. 1785-1792, 1999.

[184] A. Wicovsky, S. Salzmann, C. Roos et al., “TNF-like weak inducer of apoptosis inhibits proinflammatory TNF receptor1 signaling," Cell Death and Differentiation, vol. 16, no. 11, pp. 1445-1459, 2009. 


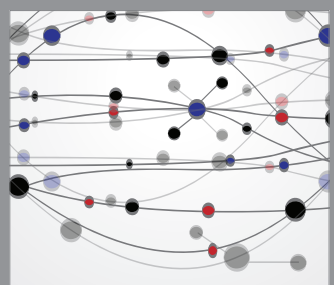

The Scientific World Journal
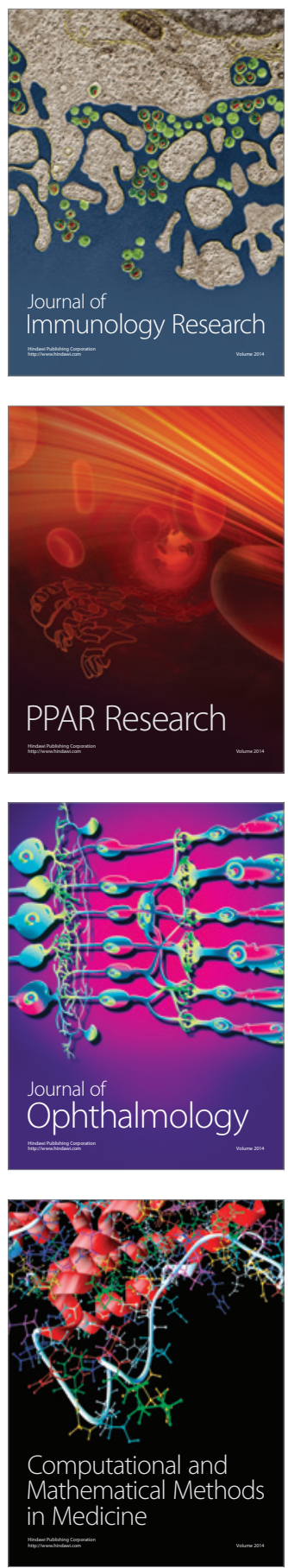

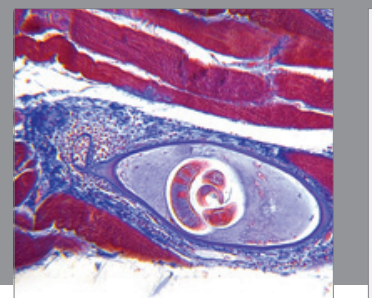

Gastroenterology

Research and Practice
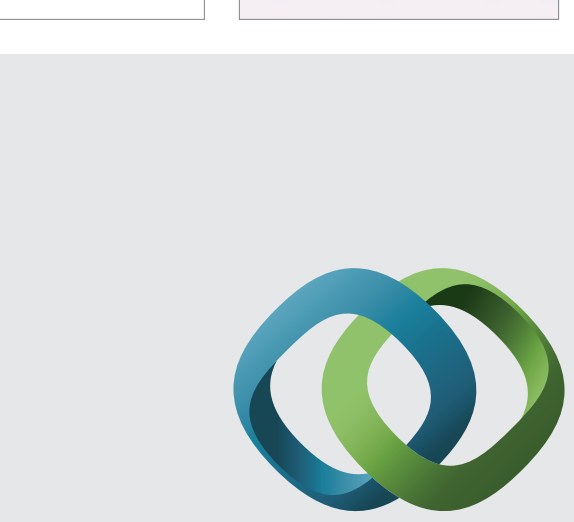

\section{Hindawi}

Submit your manuscripts at

http://www.hindawi.com
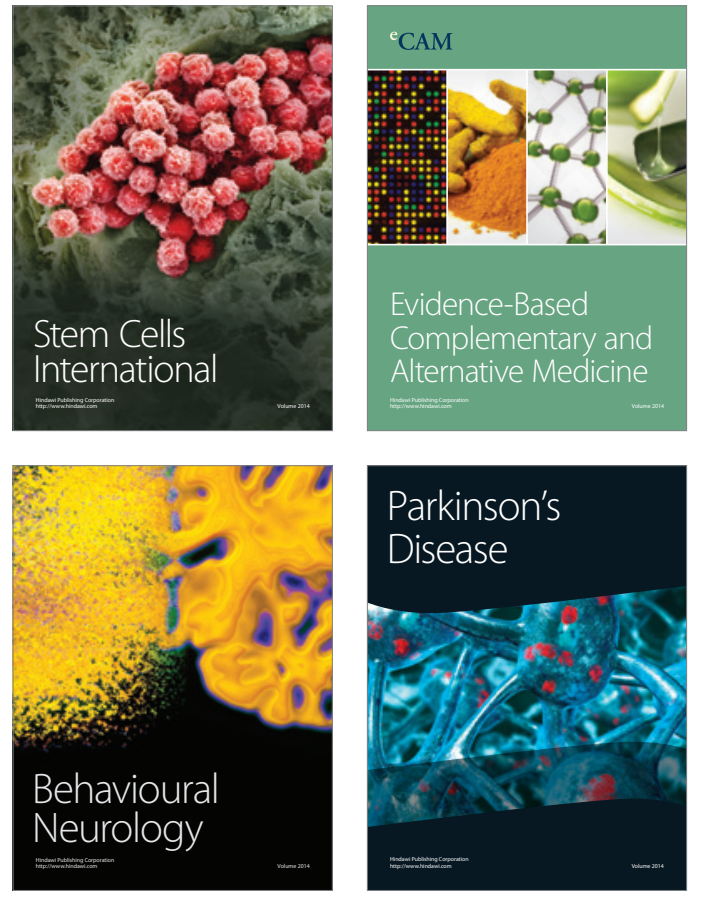
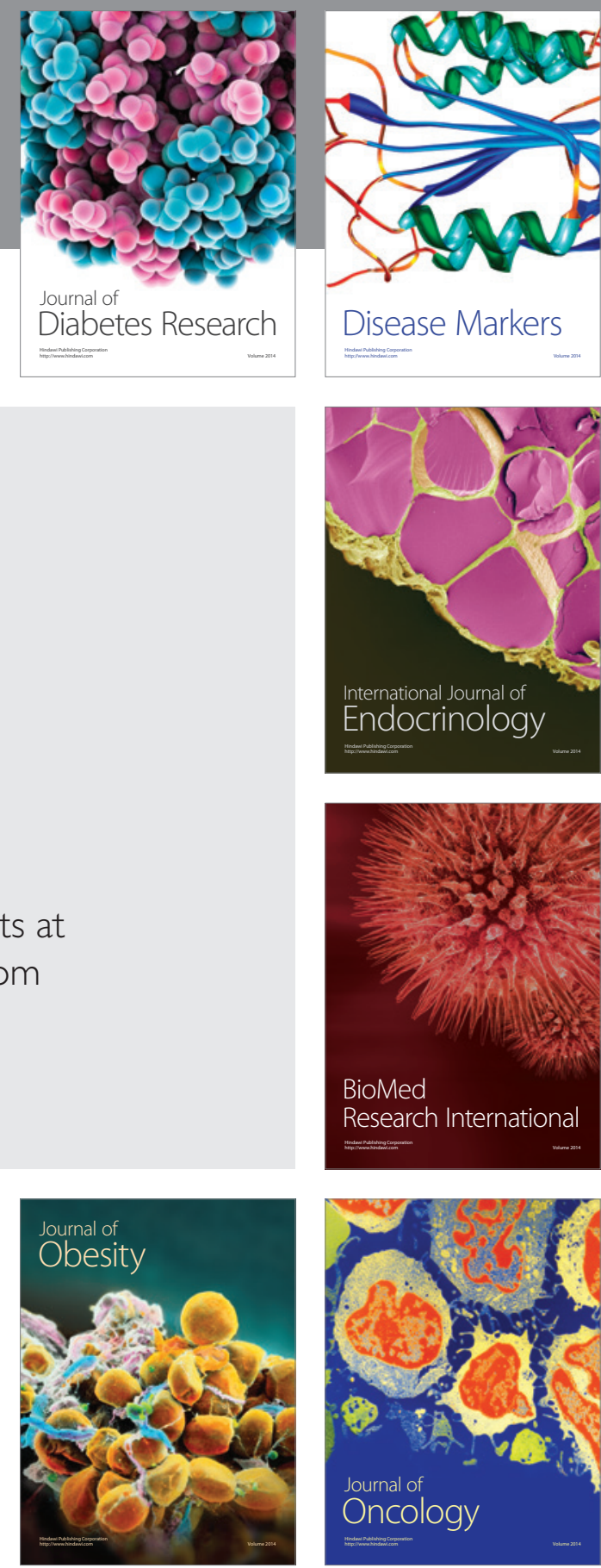

Disease Markers
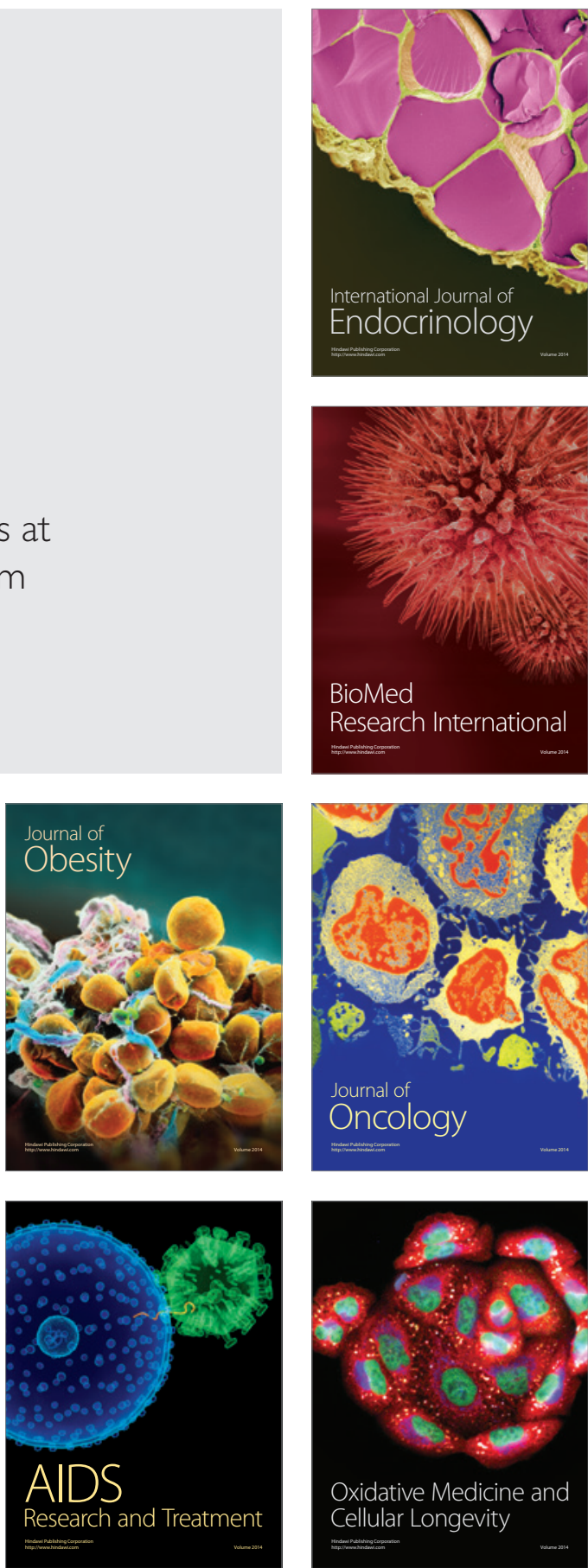